\title{
Strategic Incorporation of Polarity in Heme-Displacing Inhibitors of Indoleamine-2,3-dioxygenase-1 (IDO1)
}

Catherine White ${ }^{\star \Omega}$, Meredeth A. McGowan ${ }^{\star \Omega}$, Hua Zhou ${ }^{\Omega}$, Nunzio Sciammetta ${ }^{\Omega}$, Xavier Fradera $^{\Delta}$, Jongwon Lim $^{\Omega}$, Elizabeth M. Joshie ${ }^{\mathrm{e}}$, Christine Andrews $^{\partial}$, Elliott B. Nickbarg ${ }^{\partial}$, Phillip Cowley ${ }^{\dagger}$, Sarah Trewick ${ }^{\dagger}$, Martin Augustin ${ }^{\Sigma}$, Konstanze von Köenig ${ }^{\Sigma}$, Charles A. Lesburg $^{\Delta}$, Karin Otte ${ }^{\mathrm{e}}$, Ian Knemeyer ${ }^{\mathrm{e}}$, Hyun $\mathrm{Woo}^{\mathrm{e}}$, Wensheng $\mathrm{Yu}^{\Omega}$, Mangeng Cheng ${ }^{\Pi}$, Peter Spacciapoli ${ }^{\infty}$, Prasanthi Geda $\Pi$, Xuelei Song $\Pi$, Nadya Smotrov $\Pi$, Patrick Curran $\Pi$, Mee Ra Heo ${ }^{\Pi}$, Pravien Abeywickrema ${ }^{\Delta \dagger}$, J. Richard Miller ${ }^{\Pi}$, David Jonathan Bennett ${ }^{\Omega}$, and Yongxin $\operatorname{Han}^{\Omega}$

${ }^{\Omega}$ Department of Chemistry, ${ }^{\Delta}$ Computational and Structural Chemistry, $\Pi_{\text {In Vitro Pharmacology, }}$

epharmacokinetics, Pharmacodynamics \& Drug Metabolism, ${ }^{\partial}$ Automated Ligand Identification System Merck \& Co., Inc., 33 Avenue Louis Pasteur, Boston, Massachusetts 02115, United States

$\Sigma$ Proteros biostructures GmbH. 82152 Martinsried, Germany

${ }^{\infty}$ Deceased April 15, 2019

\section{Supporting Information for Publication}

\section{Contents of Supporting Information for Publication}

1. Automated Ligand Identification System (ALIS) Experimental Protocol

2. IDO1 Protein Preparation

3. IDO1 Enzyme Assay Protocol

4. IDO1 Hela Assay Protocol

5. IDO1 Human Whole Blood Assay Protocol

6. High Throughput (HT) FaSSIF Solubility determination

7. Hepatocycte intrinsic clearance method

8. Metabolite Identification Experimental Information

9. Preparation of Compounds Depicted in Table 1

10. In Vivo PK Protocols and Animal Care Statements

11. Prediction of Human Pharmacokinetic Parameters and Efficacious Dose

12. Supporting Figures

13. Abbreviations used in the Supporting Information for Publication

14. References

\section{ALIS (Automated Ligand Identification System) Experimental Protocol}


ALIS affinity selection incorporates size exclusion chromatography (SEC - Column: $2.1 \mathrm{~mm}$ I.D. $\mathrm{X}$ $50 \mathrm{~mm}$ length column, packed with proprietary gel filtration media; Running buffer: $700 \mathrm{mM}$ ammonium acetate, $\mathrm{pH} 8.0$, flow rate $(\mathrm{F})=300 \mu \mathrm{L} / \mathrm{min}, 4^{\circ} \mathrm{C}$ column temperature) and reverse phase chromatography (RPC - Column: Higgins Analytical, Mountain View, CA - Targa C $18,0.5$ mm I.D. x 50 mm, $5 \mu \mathrm{m}$ packing material; Mobile Phases: Water: Acetonitrile with $0.2 \%$ formic acid, $0-90 \%$ B gradient in 2.5 minutes, $\mathrm{F}=20 \mu \mathrm{L} / \mathrm{min}, 40^{\circ} \mathrm{C}$ column temperature) coupled to high resolution mass spectrometry. Each ALIS system is comprised of a combination of isocratic and capillary binary chromatography pumps, two variable wavelength detectors, a chilled microplate autosampler (Agilent Technologies, Wilmington, DE), a custom built valve box incorporating four switching valves, and an Exactive Orbitrap mass spectrometer (Thermo Scientific, San Jose, CA). Each ALIS sample consisted of mass-encoded compound mixtures ( 1000 compounds; each present at $0.5 \mu \mathrm{M}$ ) combined with $5 \mu \mathrm{M}$ IDO1 in $50 \mathrm{mM} \mathrm{NaPi}, 150$ $\mathrm{mM} \mathrm{NaCl}, \mathrm{pH}$ 7.0, $20 \mathrm{mM}$ ascorbic acid, $20 \mu \mathrm{M}$ methylene blue with 2.5\% (v/v) residual DMSO. After 30 minute incubation at room temperature, samples were loaded into the cooled $\left(4^{\circ} \mathrm{C}\right)$ autosampler for subsequent injection and analysis. Screening was accomplished in an iterative manner, with two rounds of mixture-based screening followed by confirmation of the single, pure compound. Counter screening with $5 \mu \mathrm{M}$ Invertase eliminated compounds that exhibited non-specific binding. Compounds yielding reproducible MS signals in each subsequent experiment with IDO1, and not producing signal with invertase were considered ALIS hits.

\section{AQUEOUS DILUTION OF ALL SAMPLES}

For all experiments, each compound mixture well was then diluted with library dilution buffer (50 mM HEPES, pH 7.5, $150 \mathrm{mM} \mathrm{NaCl}$ ) up to $20 \mu \mathrm{L}$. These dilutions yielded each well at $2 \mathrm{x}$ screening concentration. When combined 1:1 with the protein solutions described in the next section, this maintained a constant screening concentration of $1 \mu \mathrm{M}$ per compound in each mixture across all screening samples. Each well had a residual amount of 5\% DMSO.

\section{IDO1 Protein Preparation}

IDO1 was expressed in E. coli (Lucigen C41(DE3) at $37^{\circ} \mathrm{C}$ using a LEX system in LB media until a OD600 of 0.8 was reached. Cells were induced with 0.5 mM IPTG and supplemented with 0.75 mM 5aminolevulinic acid and $0.1 \mathrm{mM}$ thiamine- $\mathrm{HCl}$. Cells were then grown at $27^{\circ} \mathrm{C}$ for an additional $19 \mathrm{hrs}$. (overnight) before harvesting and freezing. Cells were resuspended in Lysis buffer ( $25 \mathrm{mM} \mathrm{Tris-HCl} \mathrm{pH}$ 7.5, $150 \mathrm{mM} \mathrm{NaCl}, 20 \mathrm{mM}$ Imidazole, $40 \mathrm{U} / \mathrm{ml}$ Universal Nuclease (Pierce), complete Protease inhibitor 
cocktail EDTA-free (1/50ml), $1 \mathrm{mM}$ AEBSF, $1 \mathrm{mM}$ TCEP and lysed using a microfluidizer. The lysate was centrifuged at $45000 \times \mathrm{g}$ for 25 minutes at $4{ }^{\circ} \mathrm{C}$ and loaded onto a HisTrap FF crude column previously equilibrated with IMAC buffer (25 mM Tris-HCl pH 7.5, $150 \mathrm{mM} \mathrm{NaCl}, 20 \mathrm{mM}$ Imidazole, $1 \mathrm{mM}$ TCEP). After washing, the protein was eluted with a gradient to $100 \%$ IMAC buffer containing $500 \mathrm{mM}$ imidazole. The proteins were desalted using a HiPrep 26/10 desalting column equilibrated in $25 \mathrm{mM}$ Tris- $\mathrm{HCl} \mathrm{pH} \mathrm{7.5,} 150 \mathrm{mM} \mathrm{NaCl}, 1 \mathrm{mM}$ EDTA, and $1 \mathrm{mM}$ TCEP. Following desalting the protein was loaded onto a superdex-200 16/60 SEC column using the same buffer. Fractions were analyzed by gel electrophoresis and for heme content based on the ratio of absorbance at 406/280 nm. Fractions with the greatest purity and heme content were pooled and concentrated to $1-5 \mathrm{mg} / \mathrm{mL}$ using $10 \mathrm{kD}$ cutoff Amicon spin concentrators. Heme stoichiometry varied from 0.8-0.95 heme per IDO1 molecule.

\section{IDO1 Enzyme Assay Protocol ${ }^{1}$}

Compounds to be tested were serially diluted in ten 3-fold steps in DMSO starting from $10 \mathrm{mM}$ DMSO stocks. Compound dilutions or DMSO alone were then dispensed from the dilution plate into a Greiner black 384-well assay plate (catalog \#781086) using an Echo 555 acoustic liquid handler (Labcyte).

HIS-tagged IDO1 protein was recombinantly expressed in Escherichia coli using ZYP5052 autoinduction media supplemented with $500 \mu \mathrm{M}$ delta aminolevulinic acid for 48 hours at $16{ }^{\circ} \mathrm{C}$. IDO1 protein was purified using $\mathrm{Ni}^{2+}$-affinity resin and size exclusion chromatography. Purified protein was then diluted in assay buffer ( $50 \mathrm{mM}$ Tris $\mathrm{pH} 7.0,1 \%$ glycerol, $20 \mu \mathrm{M}$ methylene blue, $0.05 \%$ Tween-20, $20 \mathrm{mM}$ sodium ascorbate, 100 units $/ \mathrm{mL}$ catalase to obtain a final IDO1 concentration of $40 \mathrm{nM}$. IDO1 solution $(30 \mu \mathrm{M})$ or buffer alone $(30 \mu \mathrm{M})$ were dispensed to wells of the assay plate using a BioRAPTR liquid dispenser (Beckman Coulter). Assay plates containing compound and IDO1 enzyme were incubated at room temperature for 30 minutes. Afterwards, $10 \mu \mathrm{L}$ of $400 \mu \mathrm{M}$ tryptophan in assay buffer were added to each well of the assay plate using a BioRAPTR liquid dispenser. Plates were incubated at room temperature for 60 minutes and reactions were quenched by addition of $10 \mu \mathrm{L}$ of $0.5 \mathrm{M}$ methyl isonipecotate in dimethyl sulfoxide. Plates were sealed and incubated at $37^{\circ} \mathrm{Celsius}$ for 4 hours or 50 ${ }^{\circ} \mathrm{C} e l s i u s$ for 2 hours. The plates are allowed to cool and then centrifuged for 1 minute at 1000xg. The resulting fluorescence was measured in an Envision plate reader (Perkin Elmer) with a 400/25 nm excitation filter and an 510/20 nm emission filter.

The fluorescence intensity of each well was corrected for the background observed in wells that did not receive IDO1 and was expressed as a fraction of the intensity observed in wells that received 
IDO1 enzyme and DMSO only. Potencies were calculated by linear least squares fit to the four parameter logistic $I C_{50}$ equation. Compounds found in Table 1 were tested in this assay and found to be inactive.

\section{IDO1 Hela Assay Protocol (Table 1) ${ }^{1}$}

Hela cells were cultured in complete Hela culture medium (90\% EMEM, 10\% heat-inactivated fetal bovine serum) and expanded to about $1 \times 109$ cells. The cells were then collected and frozen down at $10 \times 106$ cells/vial in $1 \mathrm{~mL}$ frozen medium (90\% complete Hela culture medium, 10\% DMSO).

Compounds to be tested were serially diluted in ten 3-fold steps in DMSO starting from $10 \mathrm{mM}$ DMSO stocks in Echo low volume plate(s). Compound dilutions or DMSO alone were then dispensed from the dilution plate(s) into Greiner black 384-well assay plate(s) (catalog \#781086, $50 \mathrm{~nL} /$ well) using an Echo 550 acoustic liquid handler (Labcyte).

Frozen Hela cells were thawed and transferred into Hela assay medium ( $99 \%$ complete Hela culture medium, 1\% Pen/Strep) with $20 \mathrm{~mL}$ medium/vial of cells. The cells were spun down at $250 \mathrm{~g}$ in a table top centrifuge for $5 \mathrm{~min}$ and suspended in same volume of Hela assay medium. The cells were then counted and adjusted to a density of $2 \times 105$ cells $/ \mathrm{ml}$ in Hela assay medium. Sterile L-tryptophan were added to the cells with final concentration of $300 \mathrm{uM} \mathrm{L-tryptophan.} \mathrm{A} \mathrm{small} \mathrm{aliquot}(2 \mathrm{~mL} / \mathrm{plate})$ of Hela cells were set aside and were not treated with IFN $\gamma$, to serve as the Max-E control. The rest of Hela cells were added with sterile IFNy (Cat\# 285-IF, R \& D systems) with a final concentration of $100 \mathrm{ng} / \mathrm{mL}$.

Hela cells with and without IFNy were dispensed to the respective wells of 384-well assay plates containing the compounds. The plates were incubated for about 48 hours at $37{ }^{\circ} \mathrm{C}, 5 \% \mathrm{CO}_{2}$ incubator. Afterwards, $12 \mu \mathrm{L}$ of $0.5 \mathrm{M}$ methyl isonipecotate in dimethyl sulfoxide were added into each well and the plates were sealed and incubated at $37{ }^{\circ} \mathrm{C}$ without $\mathrm{CO}_{2}$ overnight. The plates were centrifuged for 1 min at 200xg. The resulting fluorescence was measured in a Spectramax plate reader (Molecular Devices) with a $400 \mathrm{~nm}$ excitation filter and a $510 \mathrm{~nm}$ emission filter.

The fluorescence intensity of each well was corrected for the background observed in wells with non-IFN $\gamma$-treated cells and was expressed as a fraction of the intensity observed in wells of IFN $\gamma$-treated cells and DMSO only. Potencies were calculated by linear least squares fit to the four parameter logistic $I C_{50}$ equation. $I C_{50}$ values reported are the mean of at least $n=2$ values unless otherwise noted, and potency values differed by less than 3-fold, otherwise additional replicate data were collected.

The using the IDO1 cellular assay described above are summarized in Table 1. 


\section{IDO1 Human Whole Blood Assay Protocol (Table 1) ${ }^{1}$}

Compounds to be tested were serially diluted in ten 3-fold steps in DMSO starting from $10 \mathrm{mM}$. $3 \mu \mathrm{L}$ of compound dilutions or DMSO alone were then dispensed from the dilution plate into a polypropylene 96-well assay plate containing $97 \mu \mathrm{L}$ of RPMI using an Echo 555 acoustic liquid handler (Labcyte). LPS and IFN $\gamma$ was prepared in RPMI to a $10 X$ of final conc. (1000 ng/mL), final concentration is $100 \mathrm{ng} / \mathrm{mL}$.

Human whole blood was drawn in sodium heparin coated tubes from healthy internal donors. $240 \mu \mathrm{L}$ of blood was transferred to each of the wells of a v-bottom 96 well plate. $30 \mu \mathrm{L}$ of compound was transferred from intermediate dilution plate, and incubated for $15 \mathrm{~min}$. $30 \mu \mathrm{L}$ from stimulants was then transferred to blood and mixed thoroughly. Plate was covered with breathable membrane and incubated at $37^{\circ} \mathrm{C}$ for overnight (18 h).

On day 2 isotope labeled standard of kynurenine and tryptophan was made in water at 10x concentration and $30 \mu \mathrm{L}$ was added to the blood at $3 \mu \mathrm{M}$ final concentration. The assay plates were centrifuged at 300xG for 10 min with no brake to separate plasma from red blood cells. $60 \mu \mathrm{L}$ of plasma samples was removed without disturbing red blood cells. Plasma was diluted with RPMI in 1:1 ratio and proteins were precipitated out with two volume of Acetonitrile. The plates was centrifuged at $4000 \times \mathrm{x}$ for $60 \mathrm{~min}$. $20 \mu \mathrm{L}$ of supernatant was carefully transferred to a 384 well plate containing $40 \mu \mathrm{L}$ of $0.1 \%$ formic acid in water and analyzed by LC/MS/MS.

LC/MS/MS analyses were performed using Thermo Fisher's LX4-TSQ Quantum Ultra system. This system consists of four Agilent binary high-performance liquid chromatography (HPLC) pumps and a TSQ Quantum Ultra triple quadruple MS/MS instrument. For each sample, $5 \mu \mathrm{L}$ were injected onto an Atlantis T3 column ( $2.1 \mathrm{~mm} \times 150 \mathrm{~mm}, 3 \mu \mathrm{m}$ particle size) from Waters. The mobile phase gradient pumped at $0.8 \mathrm{~mL} / \mathrm{min}$ was used to elute the analytes from the column at $25^{\circ} \mathrm{C}$. The elution started at $0 \% \mathrm{~B}$ increasing linearly to $25 \% \mathrm{~B}$ at $6.5 \mathrm{~min}$, holding at $25 \%$ for $1 \mathrm{~min}$, re-equilibrating to $10 \mathrm{~min}$. Mobile phase A consisted of $0.1 \%$ formic acid in water. Mobile phase B consisted of $0.1 \%$ of formic acid in acetonitrile. Data was acquired in positive mode using a HESI interface. The operational parameters for the TSQ Quantum Ultra instrument were a spray voltage of $4000 \mathrm{~V}$, capillary temperature of $380^{\circ} \mathrm{C}$, vaporizer temperature $400{ }^{\circ} \mathrm{C}$, shealth gas 60 arbitrary units, Aux gas 20 arbitrary units, tube lens 85 and collision gas 1.2 mTorr. SRM chromatograms of kynurenine (Q1: 209.2>Q3:94.0) and internal standard (Q1: 215.3>Q3:98.2) were collected for 90 seconds. The peak area was integrated by Xcalibur Quan software. The ratios between the kynurenine generated in the reaction and 2D6-Kynurenine spiked-in internal standard were used to generate percentage inhibition and $\mathrm{IC}_{50}$ values. Compounds were 
titrated and $\mathrm{IC}_{50}$ s were calculated by 4 parameter sigmoidal curve fitting formula. . IC $\mathrm{C}_{50}$ values reported are the mean of at least $n=2$ values unless otherwise noted, and potency values differed by less than 3fold, otherwise additional replicate data were collected.

\section{High Throughput (HT) FaSSIF Solubility Determination (Table 1$)^{2}$}

The chromatographic system consists of an Agilent 1290 UPLC system composed of a G4220A binary pump, G7167B dual-needle autosampler, G1316C thermostatted column compartment, G4212A diode-array UV-vis detector, and ChemStation software, all from Agilent Technologies, USA.

The separations are carried out on an Acquity UPLC BEH C8, $30 \mathrm{~mm} \times 2.1 \mathrm{~mm}$ I.D., $1.7 \mu \mathrm{m}$, (Waters Corporation, USA). The mobile phase consists of water with $20 \mathrm{mM}$ ammonium bicarbonate (mobile phase A) and acetonitrile (mobile phase $\mathrm{B}$ ). The column oven temperature is set to $50^{\circ} \mathrm{C}$. The UPLC analysis consists of a gradient with a 0.6 min runtime. The injection volume is $1.5 \mu \mathrm{L}$ with alternating needles and the spectrophotometric detection is set to 215 and $238 \mathrm{~nm}$.

A $10 \mathrm{mM}$ DMSO stock solution of API is delivered for analysis. A $100 \mu \mathrm{M}$ standard solution is generated by diluting $2.5 \mu \mathrm{L}$ of the $10 \mathrm{mM}$ stock solution with $247.5 \mu \mathrm{L}$ of diluent (10\% $\mathrm{DMSO} / 10 \% \mathrm{MeCN} / 80 \% \mathrm{MeOH}, \mathrm{v} / \mathrm{v} / \mathrm{v}$ ). A solubility solution is generated by diluting $5 \mu \mathrm{L}$ of the $10 \mathrm{mM}$ stock solution with $245 \mu \mathrm{L}$ of FaSSIF solution (maximum solubility approximately $200 \mu \mathrm{M})$. The solubility solution is equilibrated overnight at $25^{\circ} \mathrm{C}$ with gentle shaking. The equilibrated solubility solution is filtered by centrifugation ( 3 minutes at $4000 \mathrm{rpm}$ ) using a 0.45 $\mu \mathrm{m}$ filter with a polypropylene membrane. The standard solution and the filtered equilibrated solubility solution are analyzed by UPLC/DAD. The solubility value is calculated by the following equation:

Solubility $=($ Peak area of sample $/$ Peak area of standard) (Standard concentration)

\section{Hepatocycte intrinsic clearance method (Table 1$)^{2}$}

The in vitro intrinsic clearances were determined in cryopreserved rat, dog, and human hepatocytes using a standard substrate depletion method, and were quantified via LC-MS/MS.8 Compounds were incubated for $120 \mathrm{~min}$ at $0.3 \mathrm{mM}$ in Krebs-Henseleit buffer containing 2_106 hepatocytes/ml, and the initial slope of the substrate disappearance curve (In peak area ratio versus time) was used to calculate the intrinsic clearance. 


\section{Metabolite Identification Experimental Information (Figure 3)}

Rat and Human Microsomal Incubations. The experiments were performed in 96-well plates at $37^{\circ} \mathrm{C}$. Test articles at a concentration of $2 \mathrm{mM}$ in pure DMSO were diluted 1:1000 in 8.5\% DMSO in acetonitrile to $30 \mu \mathrm{M}$. This solution $(5 \mu \mathrm{L})$ was added to $445 \mu \mathrm{L}$ of human or rat liver microsomal protein $(0.25$ $\mathrm{mg} / \mathrm{mL}$ final concentration) suspended in phosphate buffer $(\mathrm{pH} 7.4)$ with $2 \mathrm{mM}$ magnesium chloride. Reactions were initiated by the addition of $50 \mu \mathrm{L}$ of a cofactor solution containing $2 \mathrm{mM}$ NADPH (final concentration). At specific reaction time points $(0,5,15,30$, and $45 \mathrm{~min})$, aliquots $(50 \mu \mathrm{L})$ were removed and reactions were terminated by the addition to acetonitrile (100 $\mu \mathrm{L}$, with $0.1 \% \mathrm{v} / \mathrm{v}$ formic acid) containing the analytical internal standards (200 nM diclofenac, $200 \mathrm{nM}$ labetalol, and $200 \mathrm{nM}$ imipramine) and mixed well. Samples were centrifuged for $20 \mathrm{~min}$, after which a $40 \mu \mathrm{L}$ aliquot was transferred to a clean plate and $40 \mu \mathrm{L}$ of MilliQ water was added, mixed and injected for LC/MS analysis. The rate of parent elimination was estimated, relative to time zero minute incubation, is used to estimate the in vitro elimination-rate constant ( $\mathrm{kmic})$, which is used to calculate the in vitro metabolic clearance rates. ${ }^{3}$

Rat and Human Hepatocyte Incubations. The experiments were performed in 96 -well plates at $37^{\circ} \mathrm{C}$. Test articles at a concentration of $2 \mathrm{mM}$ in pure DMSO were diluted 1:1000 in 8.5\% DMSO in acetonitrile to $30 \mu \mathrm{M}$. This solution $(2 \mu \mathrm{L})$ was added to $198 \mu \mathrm{L}$ of human or rat liver hepatocytes (1 million viable cells $/ \mathrm{mL}$ ) suspended in glutamine enriched Williams' Medium E. At specific reaction time points $(0,15$, $30,60$ and $90 \mathrm{~min})$, aliquots $(20 \mu \mathrm{L})$ were removed and reactions were terminated by the addition to acetonitrile ( $40 \mu \mathrm{L}$, with $100 \%$ acetonitrile) containing the analytical internal standards ( $200 \mathrm{nM}$ diclofenac, $200 \mathrm{nM}$ labetalol, and $200 \mathrm{nM}$ imipramine) and mixed well. Samples were centrifuged for 20 min, after which a $40 \mu \mathrm{L}$ aliquot was transferred to a clean plate and $40 \mu \mathrm{L}$ of MilliQ water was added, mixed and injected for LC/MS analysis. The rate of parent elimination was estimated, relative to time zero minute incubation, is used to estimate the in vitro elimination-rate constant ( $\mathrm{kmic}$ ), which is used to calculate the in vitro metabolic clearance rates. ${ }^{3}$

LC-MS/MS Analysis. Analysis of samples was performed on a high performance liquid chromatographytandem mass spectrometry (LC-MS/MS) system consisting of a Thermo QE HF mass spectrometer with an electrospray ion source from Thermo Fisher Scientific Inc. (Waltham, MA). Samples were separated on a Waters Acquity BEH C18, $2.1 \mathrm{~mm} \times 100 \mathrm{~mm}, 1.7 \mu \mathrm{m}$. The components were eluted with a gradient of $0.1 \%$ formic acid (mobile phase $A$ ) versus $0.1 \%$ formic acid in acetonitrile (mobile phase B) at a flow of 
$500 \mu \mathrm{L} /$ min using the following gradient: 0 min $5 \%$ B; $0.5 \min 5 \%$; $1.25 \min 15 \%$ B; 2.75 min $50 \%$; $3.25 \min 95 \%$ B; $3.5 \min 95 \%$ B; $3.6 \min 5 \%$ B; $5.0 \min 5 \%$ B. The injection volume was $20 \mu \mathrm{L}$. The first $1.5 \mathrm{~min}$ of eluent were diverted to waste to protect an ion source from salts and polar impurities from the incubation. Predictions of metabolites were done with MetaSite 3.0 (Molecular Discovery Ltd., Middlesex, UK, www.moldiscovery.com) using the P450 liver model, reactivity correction, and a minimal mass threshold of $100 \mathrm{Da}$ for predicted metabolites. The P450 liver model displays a consensus of the SoM predictions of the three major liver isoforms CYP3A4, CYP2D6, and CYP2C9. Stereochemistry was ignored and the smaller part of complementary metabolites (cleavage) was rejected. The predicted metabolites were exported as text-file, which was used to automatically calculate, together with parent fragment information, metabolite specific selected reaction monitoring functions (SRM) for mass spectrometry analysis. The most likely structure of the product ions was determined with the help of using MetaSite integrated into our WebMetabase software (Molecular Discovery Ltd., Middlesex, UK) when needed.

\section{Preparation of Compounds Depicted in Table 1}

Commercial reagents were obtained from reputable suppliers and used as received. Solvents were purchased in septum-sealed bottles and stored under an inert atmosphere. Unless noted, reactions were sealed with septa through which an argon atmosphere or nitrogen atmosphere was introduced. Liquid reagents and solvents were transferred under nitrogen or argon via syringe. Reactions were conducted in microwave vials, pressure-relief reaction vials, or round-bottomed flasks containing Tefloncoated magnetic stir bars. Reactions were monitored by LC/MS (30 mm x 2 mm $2 \mu \mathrm{m}$ column + guard; 2 $\mu \mathrm{L}$ injection; 3\% to 98\% MeCN/water + 0.05\% TFA gradient over 2.3 minutes; $0.9 \mathrm{~mL} / \mathrm{min}$ flow; ESI; positive ion mode; UV detection at $254 \mathrm{~nm}$ ). Flash chromatography was performed on an automated purification system using pre-packed silica gel columns. Unless otherwise noted, final compounds were purified via reverse-phase preparative HPLC using an Agilent 1200 HPLC-MSD system consisting of a 6130B single quadrupole mass-selective detector (MSD), G1315B diode array detector (DAD), G2258A autosampler, two G1361A preparative pumps, one G1379A quaternary pump with degasser, one G1312A binary pump, and three G1364B fraction collectors from Agilent Technologies (Agilent Technologies, Palo Alto, CA). System control and data analysis were performed using Agilent's

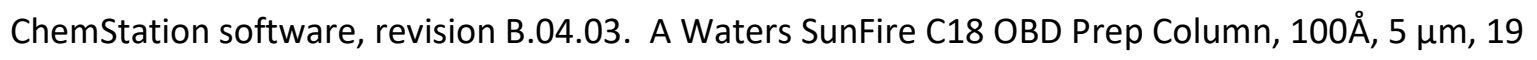
mmx150 mm column was used as the stationary phase (Waters Corporation, Milford, MA, USA). Elution 
was carried out using a gradient of $2-100 \%$ acetonitrile in water. A $10 \%$ trifluoroacetic acid solution was teed into the mobile phase as a modifier using a static mixer prior to the column, pumped at $1 \%$ of the total mobile phase flowrate. Electrospray (ESI) Mass-triggered fraction collected was employed using positive ion polarity scanning to monitor for the target mass. ${ }^{1} \mathrm{H} N \mathrm{NR}$ and ${ }^{13} \mathrm{C}$ NMR spectra were recorded on a 500 or a $600 \mathrm{MHz}$ Varian spectrometer; chemical shifts $(\delta)$ are reported relative to residual proton solvent signals. Data for NMR spectra are reported as follows: chemical shift ( $\delta \mathrm{ppm})$, multiplicity $(s=$ singlet, $b r s=$ broad singlet, $d=$ doublet, hept $=$ heptet, $\mathrm{p}=$ pentet, $\mathrm{t}=$ triplet, $\mathrm{q}=$ quartet, $d d=$ doublet of doublets, $t d=$ triplet of doublets, $m=$ multiplet), coupling constant $(\mathrm{Hz})$, integration.

\section{Compound 1: N-(4-(1-butyramidocyclobutyl)phenyl)-3-chlorobenzamide}
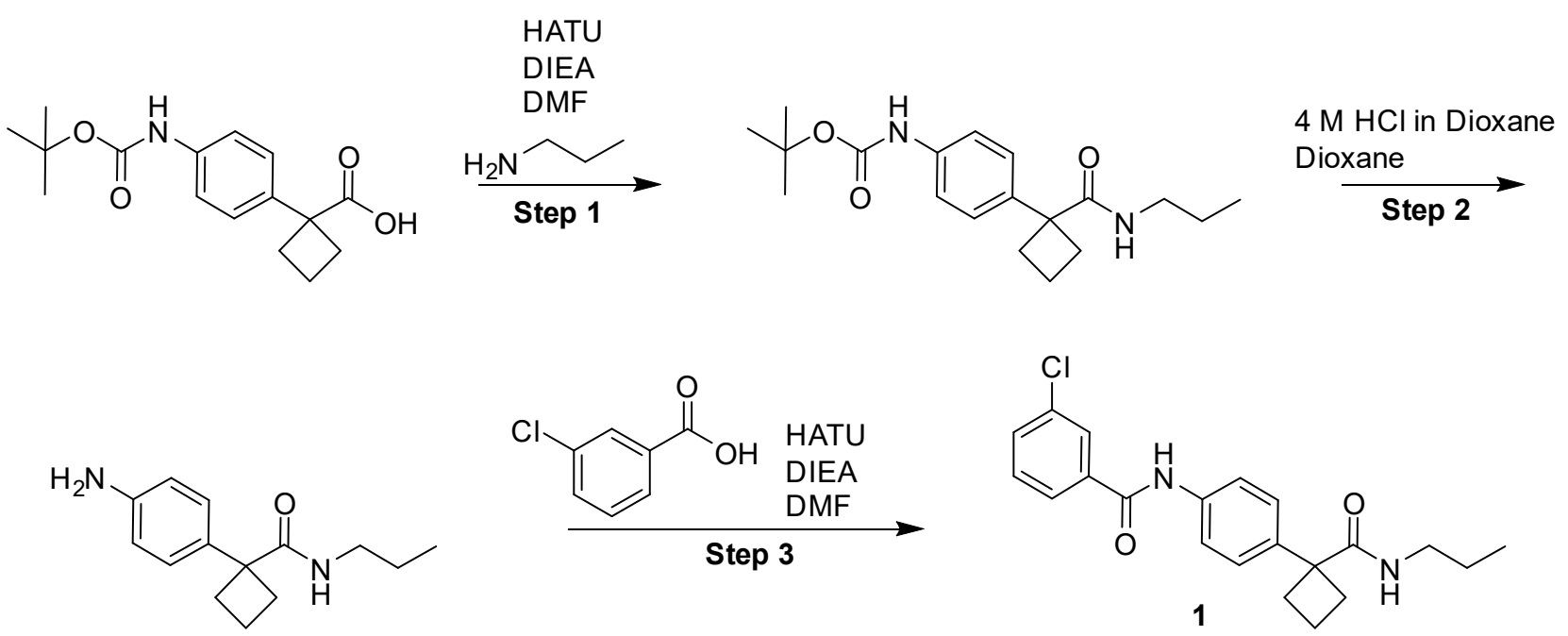

Step 1: Preparation of tert-butyl (4-(1-(propylcarbamoyl)cyclobutyl)phenyl)carbamate

To a $20 \mathrm{~mL}$ vial was added commercially available 1-(4-((tert-

butoxycarbonyl)amino)phenyl)cyclobutanecarboxylic acid (107 mg, $0.367 \mathrm{mmol}$ ), HATU (195 mg, 0.513 $\mathrm{mmol})$, and DMF $(3.0 \mathrm{ml})$. The reaction mixture was stirred at room temperature for 5 minutes. After 5 minutes, propan-1-amine $(55 \mu \mathrm{l}, 0.67 \mathrm{mmol})$ was added followed by DIPEA (185 $\mu \mathrm{l}, 1.06 \mathrm{mmol})$. The reaction was left to stir at room temperature for 1 hour. After one hour, the solvent was evaporated in vacuo. The resulting material was dissolved in DMSO $(2.0 \mathrm{~mL})$, filtered, and the reaction mixture was submitted directly for HPLC purification to the HTP group (purified by HPLC, eluting acetonitrile/water 
gradient with TFA modifier, linear gradient) to afford tert-butyl (4-(1-

(propylcarbamoyl)cyclobutyl)phenyl)carbamate (88.8 mg, $0.267 \mathrm{mmol}, 73 \%$ ).

MS (ESI) calc'd for $\mathrm{C}_{19} \mathrm{H}_{28} \mathrm{~N}_{2} \mathrm{O}_{3}[\mathrm{M}+\mathrm{H}]^{+}, 333$; found, 333.

\section{Step 2: Preparation of 1-(4-aminophenyl)-N-propylcyclobutane-1-carboxamide}

To a vial containing tert-butyl (4-(1-(propylcarbamoyl)cyclobutyl)phenyl)carbamate ( $88 \mathrm{mg}, 0.27 \mathrm{mmol})$ was added dioxane $(3.0 \mathrm{ml})$, followed by $4 \mathrm{M} \mathrm{HCl}$ in dioxane $(3.0 \mathrm{ml}, 12.0 \mathrm{mmol})$. The reaction mixture was stirred at room temperature for 16 hours. After 16 hours, the solvent was evaporated in vacuo to afford 1-(4-aminophenyl)-N-propylcyclobutanecarboxamide, $\mathrm{HCl}$ (71.1 mg, $0.27 \mathrm{mmol}, 100$ \% yield). MS (ESI) calc'd for $\mathrm{C}_{14} \mathrm{H}_{20} \mathrm{~N}_{2} \mathrm{O}[\mathrm{M}+\mathrm{H}]^{+}, 233$; found, 233.

Step 3: Preparation of 3-chloro-N-(4-(1-(propylcarbamoyl)cyclobutyl)phenyl)benzamide (1) To a vial containing 3-chlorobenzoic acid ( $70 \mathrm{mg}, 0.45 \mathrm{mmol}$ ) and HATU (171 mg, $0.45 \mathrm{mmol}$ ) was added DMF $(0.75 \mathrm{ml})$. The mixture was allowed to stir for 5 minutes. The mixture was then added to a vial containing a solution of DMF $(0.75 \mathrm{ml}), 1$-(4-aminophenyl)-N-propylcyclobutanecarboxamide, $\mathrm{HCl}(71.2$ $\mathrm{mg}, 0.27 \mathrm{mmol})$ and DIPEA $(0.231 \mathrm{ml}, 1.33 \mathrm{mmol})$. The reaction was allowed to stir at room temperature for 2 hours. After 2 hours, the solvent was evaporated in vacuo, and the residue was purified via supercritical fluid chromatography (SFC) using the following conditions: ES Basic $21 \times 250 \mathrm{~mm}$ column, 20\% $\mathrm{CO}_{2}$ in Methanol, Flow rate: $70 \mathrm{ml} / \mathrm{min}$. Compound 1 was obtained in $83 \%$ yield ( $81.5 \mathrm{mg}$ ). MS (ESI) calc'd for $\mathrm{C}_{21} \mathrm{H}_{23} \mathrm{ClN}_{2} \mathrm{O}_{2}[\mathrm{M}+\mathrm{H}]^{+}, 371$; found, 371. ${ }^{1} \mathrm{H} \mathrm{NMR}\left(600 \mathrm{MHz}\right.$, DMSO- $\left.d_{6}\right) \delta 10.35(\mathrm{~s}, 1 \mathrm{H})$, $8.04(\mathrm{~s}, 1 \mathrm{H}), 7.95(\mathrm{~d}, J=7.7 \mathrm{~Hz}, 1 \mathrm{H}), 7.76-7.68(\mathrm{~m}, 3 \mathrm{H}), 7.61(\mathrm{t}, J=7.8 \mathrm{~Hz}, 1 \mathrm{H}), 7.54(\mathrm{t}, J=5.5 \mathrm{~Hz}, 1 \mathrm{H}), 7.35$ $(\mathrm{d}, J=8.4 \mathrm{~Hz}, 2 \mathrm{H}), 3.00(\mathrm{q}, J=6.5 \mathrm{~Hz}, 2 \mathrm{H}), 2.76-2.66(\mathrm{~m}, 2 \mathrm{H}), 2.37(\mathrm{q}, J=8.7 \mathrm{~Hz}, 2 \mathrm{H}), 1.88-1.74(\mathrm{~m}, 2 \mathrm{H})$, $1.38(\mathrm{~d}, J=7.1 \mathrm{~Hz}, 2 \mathrm{H}), 0.76(\mathrm{t}, J=7.4 \mathrm{~Hz}, 3 \mathrm{H}) .{ }^{13} \mathrm{C}$ NMR $(151 \mathrm{MHz}, \mathrm{DMSO}) \delta 174.90,163.87,140.72$, $136.87,133.19$, 131.35, 130.40, 127.35, 126.45, 126.05, 120.19, 52.51, 40.54, 32.09, 22.29, 15.85, 11.18.

\section{Compound 3: 3-chloro-N-(4-(1-((4-fluorophenyl)carbamoyl)cyclobutyl)phenyl)benzamide}




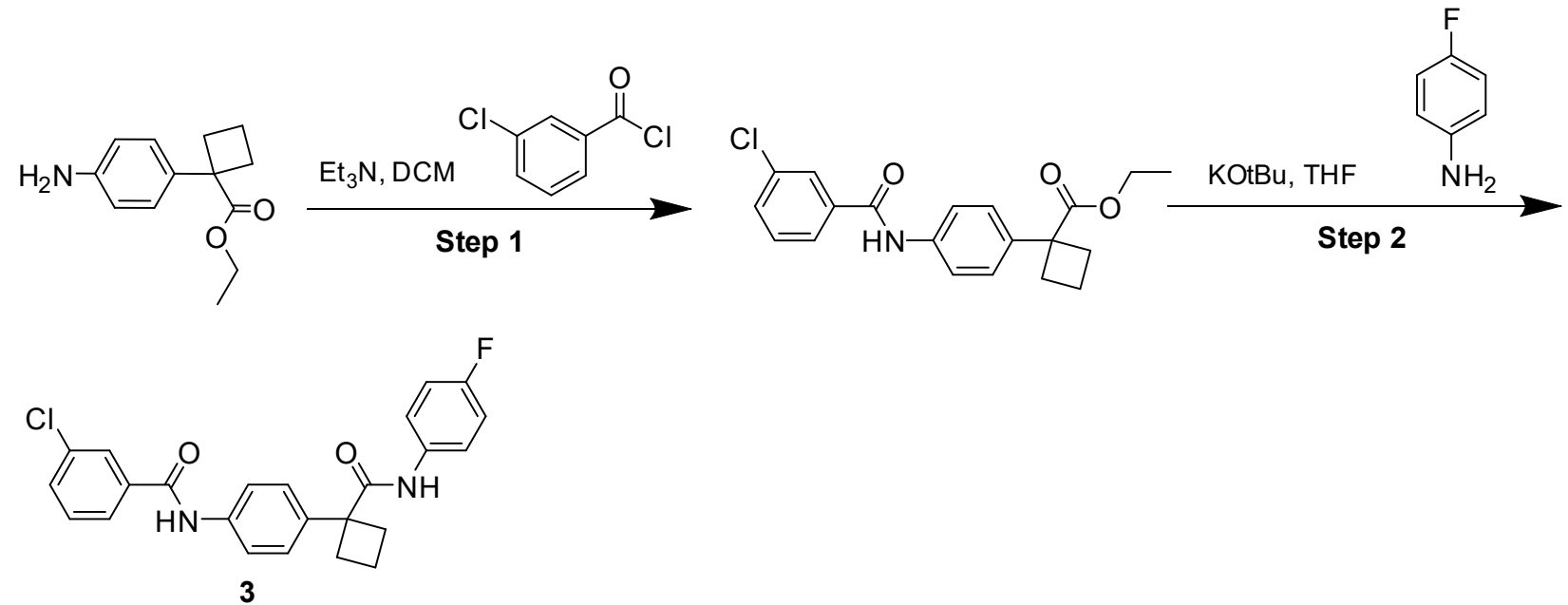

Step 1: Preparation of ethyl 1-(4-(3-chlorobenzamido)phenyl)cyclobutane-1-carboxylate

Ethyl 1-(4-aminophenyl)cyclobutanecarboxylate $(1.05 \mathrm{~g}, 4.8 \mathrm{mmol})$ was dissolved in DCM $(20 \mathrm{ml})$ and cooled to $0{ }^{\circ} \mathrm{C}$ using an ice bath. $\mathrm{Et}_{3} \mathrm{~N}(1.0 \mathrm{ml}, 7.2 \mathrm{mmol})$ and 3-chlorobenzoyl chloride $(0.77 \mathrm{ml}, 6.1$ $\mathrm{mmol}$ ) were added to the solution drop-wise at $0{ }^{\circ} \mathrm{C}$. The mixture was then warmed and stirred at room temperature for $18 \mathrm{~h}$. After 18 hours the crude reaction mixture was concentrated under reduced pressure and purified on silica gel (100 g flash column, EtOAc in hexane, 0-20\%, 5CV; 20-20\%, 10 CV) to afford ethyl 1-(4-(3-chlorobenzamido)phenyl)cyclobutanecarboxylate (1.71 g, 100\% yield). MS (ESI) Calc'd $[\mathrm{M}+\mathrm{H}]^{+}, 358$; found, 358.

Step 2: Preparation of 3-chloro-N-(4-(1-((4-fluorophenyl)carbamoyl)cyclobutyl)phenyl)benzamide (3)

To a solution of KOtBu $(27 \mathrm{mg}, 0.24 \mathrm{mmol})$ in THF $(600 \mu \mathrm{l})$ was added ethyl 1-(4-(3chlorobenzamido)phenyl)cyclobutanecarboxylate $(31 \mathrm{mg}, 0.087 \mathrm{mmol})$ and 4-fluoroaniline $(10 \mu \mathrm{l}, 0.11$ $\mathrm{mmol})$. The mixture was stirred at room temperature for $20 \mathrm{~h}$. After $20 \mathrm{~h}$ the mixture was diluted with $\mathrm{MeOH}$, filtered, and purified via reverse phase purification, (purified by HPLC, eluting acetonitrile/water gradient with TFA modifier, linear gradient) to afford the desired compound $3(2.9 \mathrm{mg}, 6.86 \mu \mathrm{mol}$, 7.92\%). MS (ESI) Calc'd for $\mathrm{C}_{24} \mathrm{H}_{20} \mathrm{ClFN}_{2} \mathrm{O}_{2}[\mathrm{M}+\mathrm{H}]^{+}$, 423; found, 423. ${ }^{1} \mathrm{H}$ NMR (600 MHz, DMSO- $\left.d_{6}\right) \delta$ $10.31(s, 1 H), 9.41(s, 1 H), 7.95(s, 1 H), 7.86(d, J=7.7 \mathrm{~Hz}, 1 \mathrm{H}), 7.69$ (d, J = 8.3 Hz, 2H), 7.62 (d, J = 7.8 Hz, $1 \mathrm{H}), 7.57(\mathrm{dd}, J=8.3,5.1 \mathrm{~Hz}, 2 \mathrm{H}), 7.52(\mathrm{t}, J=7.8 \mathrm{~Hz}, 1 \mathrm{H}), 7.40(\mathrm{~d}, J=8.3 \mathrm{~Hz}, 2 \mathrm{H}), 7.06(\mathrm{t}, J=8.7 \mathrm{~Hz}, 2 \mathrm{H})$, $2.77(\mathrm{q}, J=8.5 \mathrm{~Hz}, 2 \mathrm{H}), 2.41(\mathrm{q}, J=8.7 \mathrm{~Hz}, 2 \mathrm{H}), 1.85-1.70(\mathrm{~m}, 2 \mathrm{H}) .{ }^{13} \mathrm{C}$ NMR $(151 \mathrm{MHz}, \mathrm{DMSO}) \delta 173.95$, $163.91,158.77,157.18,139.62$, 137.24, 136.83, 135.63, 133.19, 131.38, 130.41, 127.34, 126.46, 126.18, $124.19,121.60,120.37,115.05,114.90,53.27,32.04,15.58$ (observed complexity due to C-F splitting). 


\section{Compound 5: 3-chloro-N-(4-(1-((6-chloropyridin-3-yl)carbamoyl)cyclobutyl)phenyl)benzamide}
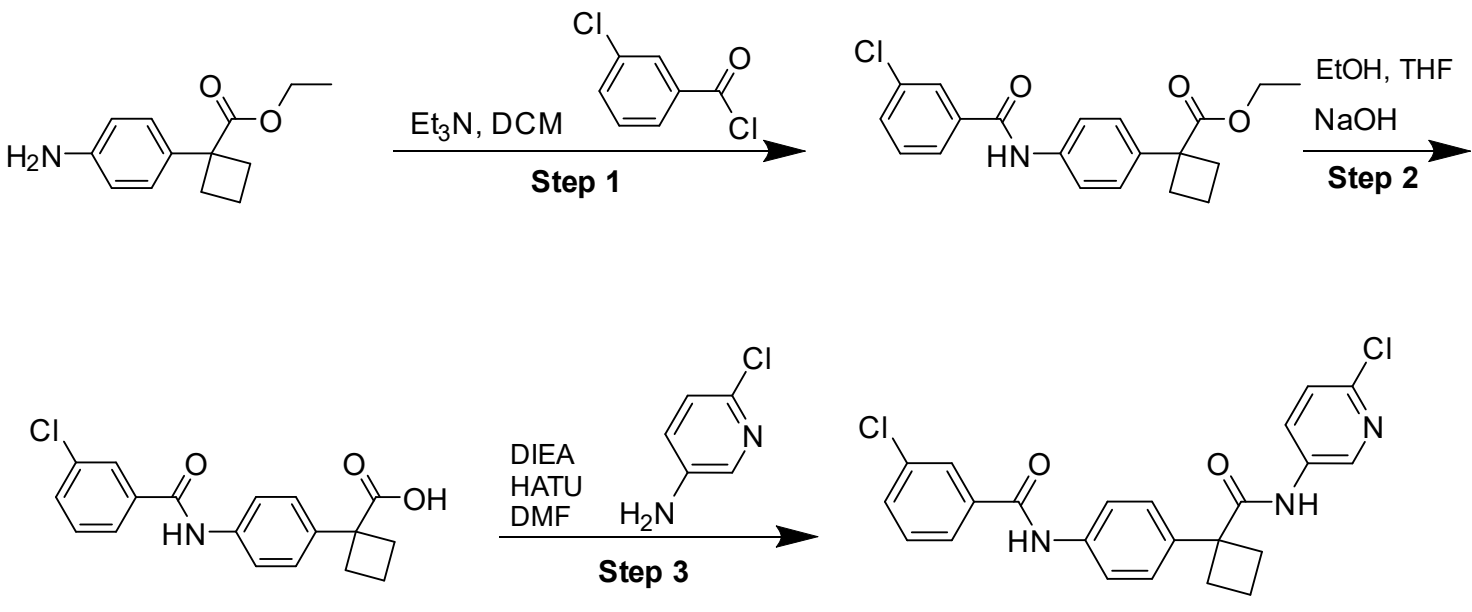

5

Step 1: Preparation of ethyl 1-(4-(3-chlorobenzamido)phenyl)cyclobutane-1-carboxylate

Ethyl 1-(4-aminophenyl)cyclobutanecarboxylate $(1.05 \mathrm{~g}, 4.8 \mathrm{mmol})$ was dissolved in DCM $(20 \mathrm{ml})$ and cooled to $0{ }^{\circ} \mathrm{C}$ using an ice bath. $\mathrm{Et}_{3} \mathrm{~N}(1.0 \mathrm{ml}, 7.2 \mathrm{mmol})$ and 3-chlorobenzoyl chloride $(0.77 \mathrm{ml}, 6.1$ $\mathrm{mmol}$ ) were added to the solution drop wise at $0{ }^{\circ} \mathrm{C}$. The mixture was stirred at room temperature for $18 \mathrm{~h}$. After 18 hours the crude reaction mixture was concentrated under reduced pressure and purified on silica gel (100 g flash column, 0-20\% EtOAc in hexane) to afford ethyl 1-(4-(3chlorobenzamido)phenyl)cyclobutanecarboxylate (1.71 g, 100\% yield). MS (ESI) Calc'd $[\mathrm{M}+\mathrm{H}]^{+}, 358$; found, 358.

Step 2: Preparation of 1-(4-(3-chlorobenzamido)phenyl)cyclobutane-1-carboxylic acid To a solution of ethyl 1-(4-(3-chlorobenzamido)phenyl)cyclobutanecarboxylate (1.7 g, $4.7 \mathrm{mmol})$ (Intermediate 4) in THF (10 ml), was added $1 \mathrm{M} \mathrm{NaOH}(10 \mathrm{ml}, 10 \mathrm{mmol})$ and ethanol $(10 \mathrm{ml})$. The mixture was stirred at room temperature for $18 \mathrm{~h}$. An additional $5 \mathrm{ml}$ of $\mathrm{NaOH}(1 \mathrm{M})$ was added and the reaction was stirred at room temperature for an additional $18 \mathrm{~h}$. After $18 \mathrm{~h}$ the crude reaction mixture was partially concentrated under reduced pressure. To the remaining aqueous solution was added $\mathrm{HCl}$ $(1 \mathrm{M})$, to adjust the $\mathrm{pH}$ to $\sim 3$. The solution was extracted with EtOAc $(x 3)$. The combined organics were 
washed with brine, dried over anhydrous $\mathrm{Na}_{2} \mathrm{SO}_{4}$, filtered, and concentrated under reduced pressure to afford 1-(4-(3-chlorobenzamido)phenyl)cyclobutanecarboxylic acid which was used without further purification. MS (ESI) Calc'd [M+H] $]^{+}, 330$; found, 330.

Step 3: Preparation of 3-chloro-N-(4-(1-((6-chloropyridin-3-yl)carbamoyl)cyclobutyl)phenyl)benzamide (5)

To a vial equipped with a stir bar was added 1-(4-(3-chlorobenzamido)phenyl)cyclobutanecarboxylic acid (20 mg, $0.061 \mathrm{mmol}$ ), 6-chloropyridin-3-amine (15.6 mg, $0.12 \mathrm{mmol}$ ), HATU (34.6 mg, $0.09 \mathrm{mmol}$ ), DMF $(500 \mu \mathrm{l})$ and DIEA $(50 \mu \mathrm{l}, 0.29 \mathrm{mmol})$. The mixture was stirred at room temperature for $18 \mathrm{~h}$. After $18 \mathrm{~h}$, the mixture was filtered and purified via mass triggered reversed phase HPLC (eluting acetonitrile/water gradient with TFA modifier, linear gradient), to afford 5 (16.2 mg, $0.03 \mathrm{mmol}, 48 \%$ yield).

MS (ESI) Calc'd C ${ }_{23} \mathrm{H}_{19} \mathrm{Cl}_{2} \mathrm{~N}_{3} \mathrm{O}_{2}[\mathrm{M}+\mathrm{H}]^{+}$, 440; found, 440. ${ }^{1} \mathrm{H}$ NMR (600 MHz, DMSO-d $\left.d_{6}\right) \delta 10.39(\mathrm{~s}, 1 \mathrm{H}), 9.79$ (s, 1H), $8.68(\mathrm{~d}, J=2.1 \mathrm{~Hz}, 1 \mathrm{H}), 8.14(\mathrm{dd}, J=8.7,2.3 \mathrm{~Hz}, 1 \mathrm{H}), 8.03(\mathrm{~s}, 1 \mathrm{H}), 7.94(\mathrm{~d}, J=7.7 \mathrm{~Hz}, 1 \mathrm{H}), 7.79(\mathrm{~d}, J$ $=8.4 \mathrm{~Hz}, 2 \mathrm{H}), 7.70(\mathrm{~d}, J=7.8 \mathrm{~Hz}, 1 \mathrm{H}), 7.61(\mathrm{t}, J=7.8 \mathrm{~Hz}, 1 \mathrm{H}), 7.51-7.43(\mathrm{~m}, 3 \mathrm{H}), 2.87(\mathrm{q}, J=8.4 \mathrm{~Hz}, 2 \mathrm{H})$, $2.52-2.46(\mathrm{~m}, 2 \mathrm{H}), 1.95-1.82(\mathrm{~m}, 2 \mathrm{H})$.

Compound 4: 3-chloro-N-(4-(1-((tetrahydro-2H-pyran-4-yl)carbamoyl)cyclobutyl)phenyl)benzamide

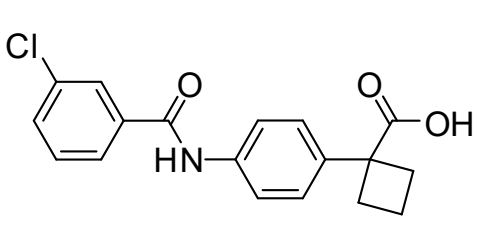

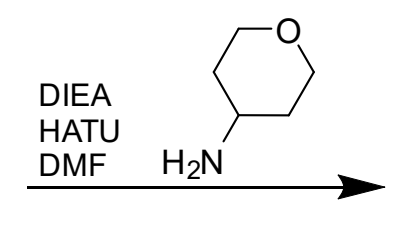

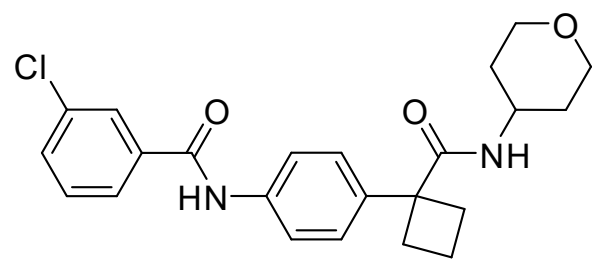

4

Compound 4 is prepared analogously to the preparation of Compound $\mathbf{5}$ described above, using tetrahydro-2H-pyran-4-amine in step 3 of the preparation for compound $\mathbf{5}$ as follows: To a vial (Vial 1) equipped with a stir bar, was added tetrahydro-2H-pyran-4-amine, $\mathrm{HCl}(16 \mathrm{mg}, 0.12 \mathrm{mmol})$, DMF (0.1 $\mathrm{ml}$ ) and DIEA (0.05 ml). To a second vial (Vial 2) was added 1-(4-(3 -chlorobenzamido)phenyl)cyclobutanecarboxylic acid (380 mg, $1.16 \mathrm{mmol})$ and DMF (9.5 ml) Lastly, added HATU (665 mg, 1.73 $\mathrm{mmol}$ ). $0.5 \mathrm{ml}$ of the solution from Vial 2, was added to Vial 1. The reaction mixture was stirred at room temperature for $18 \mathrm{~h}$. After $18 \mathrm{~h}$, the crude was filtered and purified via reverse phase purification, (purified by HPLC, eluting acetonitrile/water gradient with TFA modifier, linear gradient) to afford 4 (8.2 mg, $0.02 \mathrm{mmol}, 33 \%$ yield). MS (ESI) Calc'd $\mathrm{C}_{23} \mathrm{H}_{25} \mathrm{ClN}_{2} \mathrm{O}_{3}[\mathrm{M}+\mathrm{H}]^{+}, 412$; found, 412. 
Compound 6: 4-fluoro-3-methyl-N-(4-(1-(propylcarbamoyl)cyclobutyl)phenyl)benzamide

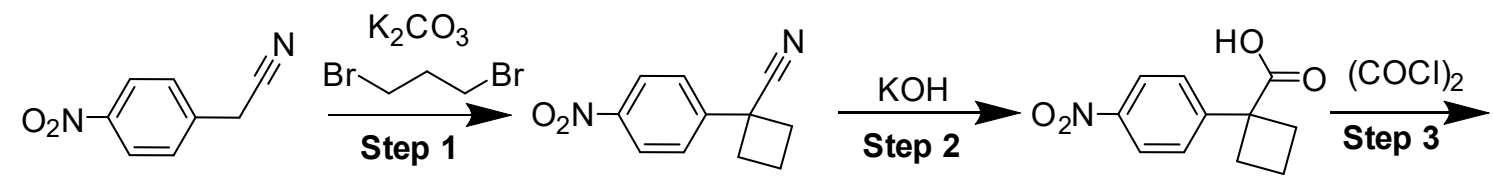<smiles>CCCNC(=O)C1(c2ccc(N)cc2)CCC1</smiles><smiles>CCCNC(=O)C1(c2ccc(NC(=O)c3ccc(F)c(C)c3)cc2)CCC1</smiles>

Step 1: Preparation of 1-(4-nitrophenyl)cyclobutanecarbonitrile

To a solution of 2-(4-nitrophenyl)acetonitrile (14 g, $89 \mathrm{mmol})$ and $\mathrm{K}_{2} \mathrm{CO}_{3}(32 \mathrm{~g}, 230 \mathrm{mmol})$ in acetone $(160 \mathrm{~mL})$, was added 1,3-dibromopropane $(22 \mathrm{~g}, 110 \mathrm{mmol})$. The solution was heated to $65^{\circ} \mathrm{C}$ and stirred for $18 \mathrm{~h}$. After $18 \mathrm{~h}$ the reaction mixture was filtered and concentrated under reduced pressure. Saturated $\mathrm{NH}_{4} \mathrm{Cl}$ solution $(200 \mathrm{~mL})$ was added and the mixture was washed with EtOAc $(200 \mathrm{~mL})$. The combined organics were concentrated under reduced pressure. The residue was purified by silica gel column chromatography (petroleum ether:EtOAc=30:1 to 5:1) to afford 1-(4-nitrophenyl)cyclobutanecarbonitrile (5.0 g, 25\% yield). ${ }^{1} \mathrm{H}$ NMR (400 MHz, CHLOROFORM-d) $\delta$ ppm 8.20 - 8.46 (m, 2 H), 7.54 $7.74(m, 2 H), 2.89-2.99(m, 2 H), 2.63-2.74(m, 2 H), 2.48-2.61(m, 1 H), 2.08-2.27(m, 1 H)$.

\section{Step 2: Preparation of 1-(4-nitrophenyl)cyclobutanecarboxylic acid}

To a solution of 1-(4-nitrophenyl)cyclobutanecarbonitrile $(1.5 \mathrm{~g}, 7.4 \mathrm{mmol})$ in EtOH $(30 \mathrm{ml}) / \mathrm{H}_{2} \mathrm{O}(10 \mathrm{ml})$ was added $\mathrm{KOH}(4.2 \mathrm{~g}, 74 \mathrm{mmol})$. The reaction mixture was stirred while refluxing for $24 \mathrm{~h}$. After $24 \mathrm{~h}$ the reaction mixture was concentrated under reduced pressure. The residue was dissolved in water (50 $\mathrm{mL})$ and the aqueous solution was washed with EtOAc $(40 \mathrm{~mL} \times 2)$. The $\mathrm{pH}$ of the aqueous mixture was 
adjusted to $\sim 2.0$ (with drop wise addition of $3 \mathrm{M} \mathrm{HCl}$ ) and was washed with EtOAc $(50 \mathrm{~mL} \times 2)$. The combined organics were washed with brine $(25 \mathrm{~mL})$, dried over anhydrous sodium sulfate, filtered, and concentrated under reduced pressure to afford 1-(4-nitrophenyl)cyclobutanecarboxylic acid. ${ }^{1} \mathrm{H}$ NMR (400 MHz, CHLOROFORM-d) $\delta$ ppm 8.17 - 8.39 (m, 2 H), 7.45 - 7.65 (m, 2 H), 5.84 (br s, 1 H), 5.09 - 5.41 (m, 1 H), 2.80 - 3.09 (m, 2 H), 2.43 - 2.66 (m, 2 H), 2.11 - 2.29 (m, 1 H), 1.94 (dtt, J=11.11, 9.29, 9.29, 5.41, $5.41 \mathrm{~Hz}, 1 \mathrm{H})$.

Step 3: Preparation of 1-(4-nitrophenyl)cyclobutanecarbonyl chloride

To a solution of 1-(4-nitrophenyl)cyclobutanecarboxylic acid (900 mg, $4.1 \mathrm{mmol}$ ) in DCM (20 ml) was added oxalyl dichloride $(1030 \mathrm{mg}, 8.1 \mathrm{mmol})$ at $0{ }^{\circ} \mathrm{C}$, drop wise. The mixture was stirred at room temperature for $2 \mathrm{~h}$. After $2 \mathrm{~h}$, the reaction mixture was concentrated under reduced pressure to afford 1-(4-nitrophenyl)cyclobutanecarbonyl chloride which was used without further purification.

Step 4: Preparation of 1-(4-nitrophenyl)-N-propylcyclobutanecarboxamide

To a solution of propan-1-amine $(330 \mathrm{mg}, 5.6 \mathrm{mmol})$ and $\mathrm{Et}_{3} \mathrm{~N}(1.6 \mathrm{ml}, 11 \mathrm{mmol})$ in DCM $(15 \mathrm{~mL})$ was added a solution of 1-(4-nitrophenyl)cyclobutanecarbonyl chloride (900 mg, $3.8 \mathrm{mmol})$ in DCM (5 mL) at $0{ }^{\circ} \mathrm{C}$. The reaction mixture was stirred at $0{ }^{\circ} \mathrm{C}$ for $1 \mathrm{~h}$. After $1 \mathrm{~h}$ the reaction mixture was diluted with $\mathrm{DCM}(50 \mathrm{~mL})$ and washed with aqueous $1.0 \mathrm{M} \mathrm{HCl}(20 \mathrm{~mL} \times 2)$. The resulting organics were washed with saturated $\mathrm{NaHCO}_{3}(20 \mathrm{~mL})$, and brine $(20 \mathrm{~mL})$. The combined organics were dried over anhydrous sodium sulfate, filtered, and concentrated under reduced pressure to afford 1-(4-nitrophenyl)-Npropylcyclobutanecarbo-xamide which was used without further purification. MS (ESI) Calc'd [M+H] ${ }^{+}$, 263; found, 263.

Step 5: Preparation of 1-(4-aminophenyl)-N-propylcyclobutanecarboxamide

To a solution of 1-(4-nitrophenyl)-N-propylcyclobutanecarboxamide (900 mg, $3.43 \mathrm{mmol}$ ) in EtOAc (30 $\mathrm{ml}$ ) was added Pd/C (100 mg, $0.094 \mathrm{mmol})$. The reaction mixture was stirred under $15 \mathrm{PSI}_{2}$ at room temperature for $1 \mathrm{~h}$. After $1 \mathrm{~h}$ the reaction mixture was filtered, and the filter cake was washed with EtOAc $(100 \mathrm{~mL})$. The resulting filtrate was concentrated under reduced pressure to afford 1-(4aminophenyl)-N-propylcyclobutanecarboxamide which was used without further purification. MS (ESI) Calc'd $[\mathrm{M}+\mathrm{H}]^{+}, 233$; found, 233.

Step 6: Preparation of 4-fluoro-3-methyl-N-(4-(1-(propylcarbamoyl)cyclobutyl)phenyl)

Benzamide (6) 
To a solution of 1-(4-aminophenyl)-N-propylcyclobutanecarboxamide (100 mg, $0.43 \mathrm{mmol}$ )

(Intermediate 5) and TEA $(0.180 \mathrm{ml}, 1.29 \mathrm{mmol})$ in DCM $(5 \mathrm{~mL})$, was added 4-fluoro-3-methylbenzoyl chloride $(150 \mathrm{mg}, 0.86 \mathrm{mmol})$ in DCM $(2 \mathrm{~mL})$ while stirring at $0{ }^{\circ} \mathrm{C}$. The reaction mixture was stirred at $0{ }^{\circ} \mathrm{C}$ for $1 \mathrm{~h}$. After $1 \mathrm{~h}$ the reaction mixture was diluted with water $(100 \mathrm{~mL})$ and washed with EtOAC $(50 \mathrm{~mL} \times 2)$. The combined organics were washed with aqueous $\mathrm{NaHCO}_{3}(100 \mathrm{~mL})$, dried over anhydrous $\mathrm{Na}_{2} \mathrm{SO}_{4}$, filtered, and concentrated under reduced pressure. The residue was purified via reverse-phase purification using a Gilson system consisting of UV-156 detector, GX281 liquid handler,

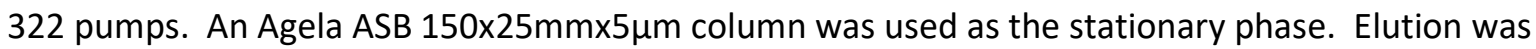
carried out using a gradient of $37-100 \%$ acetonitrile in water. A $0.2 \%$ trifluoroacetic acid solution was teed into the mobile phase (solvent $A$ ) as a modifier.

The desired product 6 was obtained in $54 \%$ yield ( $86.2 \mathrm{mg}, 0.23 \mathrm{mmol}$ ). MS (ESI) Calc'd $\mathrm{C}_{22} \mathrm{H}_{25} \mathrm{FN}_{2} \mathrm{O}_{2}$ $[\mathrm{M}+\mathrm{H}]^{+}$, 369; found, 369. ${ }^{1} \mathrm{H}$ NMR (400 MHz, DMSO- $\left.d_{6}\right) \delta 10.2(\mathrm{~s}, 1 \mathrm{H}), 7.9$ (dd, J=7.5, $\left.1.8 \mathrm{~Hz}, 1 \mathrm{H}\right), 7.8$ $7.9(\mathrm{~m}, 1 \mathrm{H}), 7.7(\mathrm{~d}, J=8.7 \mathrm{~Hz}, 2 \mathrm{H}), 7.5(\mathrm{t}, J=5.8 \mathrm{~Hz}, 1 \mathrm{H}), 7.3-7.3(\mathrm{~m}, 3 \mathrm{H}), 3.0(\mathrm{q}, J=6.7 \mathrm{~Hz}, 2 \mathrm{H}), 2.7(\mathrm{dq}$, $J=8.3,6.1 \mathrm{~Hz}, 2 \mathrm{H}), 2.3-2.4(\mathrm{~m}, 5 \mathrm{H}), 1.7-1.9(\mathrm{~m}, 2 \mathrm{H}), 1.3(\mathrm{sxt}, J=7.2 \mathrm{~Hz}, 2 \mathrm{H}), 0.7(\mathrm{t}, J=7.4 \mathrm{~Hz}, 3 \mathrm{H}) .{ }^{13} \mathrm{C}$ NMR $\left(151 \mathrm{MHz}, \mathrm{DMSO}-d_{6}\right) \delta 174.93,161.72,140.44,137.11,131.37,127.58,126.01,124.41,124.29$, $120.11,114.99,114.84,52.49,40.53,32.08,22.29,15.85,14.18,11.17$.

\section{Compound 7: 1-methyl-N-(4-(1-(propylcarbamoyl)cyclobutyl)phenyl)-1H-1,2,3-triazole-4-carboxamide}
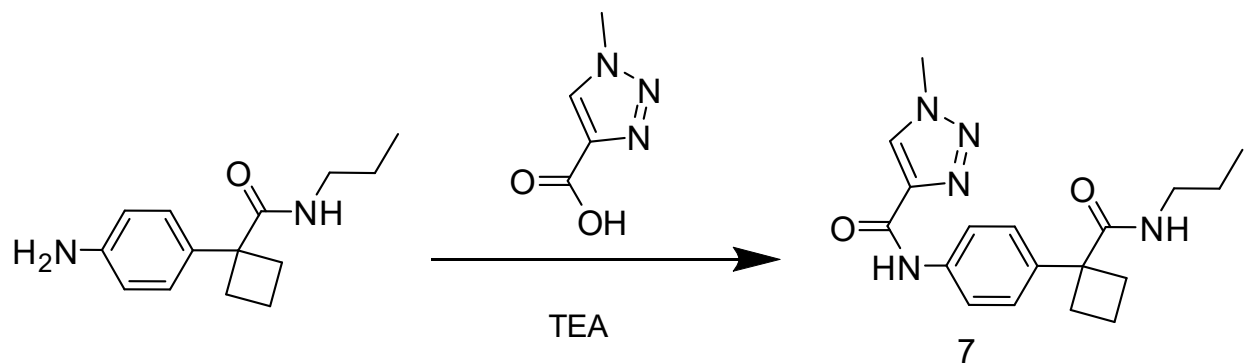

Compound 7 was prepared in an analogous fashion to compound 6, step 6 using 1-methyl-1H-1,2,3triazole-4-carboxylic acid as follows: To a vial equipped with a stir bar was added HATU (1.30 g, 3.44 $\mathrm{mmol}$ ) and DMF (12.3 ml). $300 \mu \mathrm{l}$ of this solution was added to a vial (Vial 1) containing 1-methyl-1H1,2,3-triazole-4-carboxylic acid (12 mg, $0.1 \mathrm{mmol}$ ). The mixture was stirred at room temperature. To a second vial (Vial 2) was added 1-(4-aminophenyl)-N-propylcyclobutanecarboxamide, $\mathrm{HCl}$ (615 mg, 3.30 mmol), DMF (12.3 ml), and DIEA $(4.1 \mathrm{ml}, 23.5 \mathrm{mmol}) .400 \mu \mathrm{L}$ of this solution from Vial 2 was added to 
Vial 1. The mixture was stirred at room temperature for 18 hours. After 18 hours, the mixture was evaporated via a GeneVac. The residue was purified via reverse phase purification, (purified by HPLC, eluting acetonitrile/water gradient with TFA modifier, linear gradient) to afford $\mathbf{7}$ (12.5 mg, 0.035 mmol, $63 \%$ yield). MS (ESI) calc'd for C18H23N5O2 [M+H]+, 342; found, 342. ${ }^{1} \mathrm{H} \mathrm{NMR} \mathrm{(500} \mathrm{MHz,}$ DMSO- $\left.d_{6}\right) \delta 10.25(\mathrm{~s}, 1 \mathrm{H}), 9.59(\mathrm{~s}, 1 \mathrm{H}), 8.78(\mathrm{~s}, 1 \mathrm{H}), 8.55(\mathrm{~d}, J=6.5 \mathrm{~Hz}, 1 \mathrm{H}), 8.09(\mathrm{~d}, J=6.5 \mathrm{~Hz}, 1 \mathrm{H}), 7.74$ $(\mathrm{d}, J=8.6 \mathrm{~Hz}, 2 \mathrm{H}), 7.58(\mathrm{t}, J=5.7 \mathrm{~Hz}, 1 \mathrm{H}), 7.37(\mathrm{~d}, J=8.6 \mathrm{~Hz}, 2 \mathrm{H}), 3.01(\mathrm{q}, J=6.6 \mathrm{~Hz}, 2 \mathrm{H}), 2.78-2.65(\mathrm{~m}$, $2 \mathrm{H}), 2.38(\mathrm{q}, J=8.7 \mathrm{~Hz}, 2 \mathrm{H}), 1.92-1.72(\mathrm{~m}, 2 \mathrm{H}), 1.38(\mathrm{~h}, J=7.3 \mathrm{~Hz}, 2 \mathrm{H}), 0.76(\mathrm{t}, J=7.4 \mathrm{~Hz}, 3 \mathrm{H})$.

\section{Compound 8: 5-methyl-N-(4-(1-(propylcarbamoyl)cyclobutyl)phenyl)isoxazole-4-carboxamide}

Compound 8 was prepared in an analogous fashion to compound 6, step 6 using 5-methylisoxazole-4carboxylic acid as follows: To a vial equipped with a stir bar was added HATU (1.30 g, $3.44 \mathrm{mmol})$ and DMF (12.3 ml). $300 \mu \mathrm{l}$ of this solution was added to a vial (Vial 1) containing 5-methylisoxazole-4carboxylic acid (12 mg, $0.1 \mathrm{mmol})$. The mixture was stirred at room temperature. To a second vial (Vial 2) was added 1-(4-aminophenyl)-N-propylcyclobutanecarboxamide, $\mathrm{HCl}$ (615 mg, $3.30 \mathrm{mmol}$ ), DMF (12.3 ml), and DIEA $(4.1 \mathrm{ml}, 23.49 \mathrm{mmol}) .400 \mu \mathrm{L}$ of this solution from Vial 2 was added to Vial 1. The mixture was stirred at room temperature for 18 hours. After 18 hours, the mixture was evaporated in a GeneVac. The residue was purified via reverse phase purification, (purified by HPLC, eluting acetonitrile/water gradient with TFA modifier, linear gradient) to afford 8 (8.6 mg, 0.024 mmol, $43 \%$ yield). MS (ESI) calc'd for $\mathrm{C} 19 \mathrm{H} 23 \mathrm{~N} 3 \mathrm{O} 3[\mathrm{M}+\mathrm{H}]+, 342$; found, $342 .{ }^{1} \mathrm{H} \mathrm{NMR}(500 \mathrm{MHz}$, DMSO- $\left.d_{6}\right) \delta 10.49(\mathrm{~s}, 1 \mathrm{H}), 10.22(\mathrm{~s}, 1 \mathrm{H}), 8.50(\mathrm{~s}, 1 \mathrm{H}), 8.17(\mathrm{dd}, J=8.0,1.7 \mathrm{~Hz}, 2 \mathrm{H}), 7.86(\mathrm{t}, J=7.9 \mathrm{~Hz}$, $1 \mathrm{H}), 7.74(\mathrm{~d}, J=8.6 \mathrm{~Hz}, 2 \mathrm{H}), 7.58(\mathrm{t}, J=5.7 \mathrm{~Hz}, 1 \mathrm{H}), 7.37(\mathrm{~d}, J=8.6 \mathrm{~Hz}, 2 \mathrm{H}), 3.00(\mathrm{q}, J=6.6 \mathrm{~Hz}, 2 \mathrm{H}), 2.78$ $-2.66(\mathrm{~m}, 2 \mathrm{H}), 2.44-2.29(\mathrm{~m}, 2 \mathrm{H}), 1.91-1.69(\mathrm{~m}, 2 \mathrm{H}), 1.37(\mathrm{~h}, J=7.2 \mathrm{~Hz}, 2 \mathrm{H}), 0.75(\mathrm{t}, J=7.4 \mathrm{~Hz}, 3 \mathrm{H})$.

\section{Compound 9: 3-chloro-N-(5-(1-(propylcarbamoyl)cyclobutyl)pyridin-2-yl)benzamide}



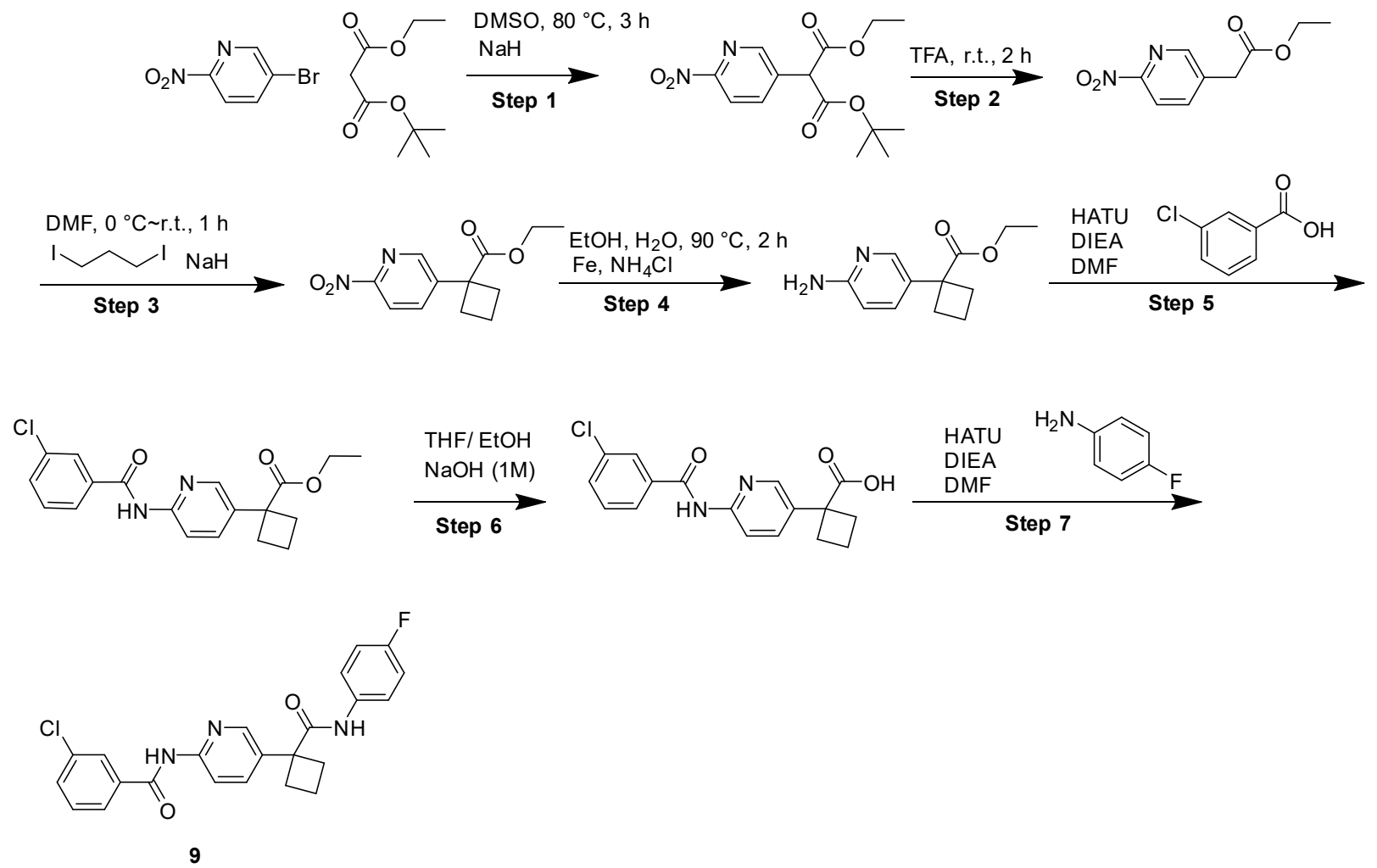

Step 1: Preparation of 1-tert-butyl 3-ethyl 2-(6-nitropyridin-3-yl)malonate

To a solution of tert-butyl ethylmalonate $(110 \mathrm{~g}, 590 \mathrm{mmol})$ in DMSO $(150 \mathrm{~mL})$ was added $\mathrm{NaH}(24 \mathrm{~g}$, $590 \mathrm{mmol}$ ) (60\% in oil) while stirring at room temperature. The reaction was stirred at room temperature for $30 \mathrm{~min}$. After $30 \mathrm{~min}$, 5-bromo-2-nitropyridine (60 g, $300 \mathrm{mmol})$ was added and the reaction mixture was heated to $80^{\circ} \mathrm{C}$. After $3 \mathrm{~h}$ of stirring at $80^{\circ} \mathrm{C}$, the reaction mixture was cooled to room temperature. To the reaction mixture was added saturated $\mathrm{NH}_{4} \mathrm{Cl}(500 \mathrm{~mL})$ and $\mathrm{H}_{2} \mathrm{O}(1000 \mathrm{~mL})$. The mixture was washed with EtOAc $(800 \mathrm{~mL} \times 2)$. The combined organics were washed with brine $(500$ $\mathrm{mL}$ ), dried over $\mathrm{Na}_{2} \mathrm{SO}_{4}$, filtered, and concentrated under reduced pressure. The residue was purified by silica gel chromatography (Petroleum ether/EtOAc= 10:1 to 5:1) to afford 1-tert-butyl 3-ethyl 2-(6nitropyridin-3-yl)malonate (87 g, 95\% yield). MS (ESI) calc'd for $\mathrm{C}_{14} \mathrm{H}_{18} \mathrm{~N}_{2} \mathrm{O}_{6}[\mathrm{M}+\mathrm{H}]^{+}, 311$; found, 311 .

\section{Step 2: Preparation of ethyl 2-(6-nitropyridin-3-yl)acetate}

A solution of 1-tert-butyl 3-ethyl 2-(6-nitropyridin-3-yl)malonate (87 g, $280 \mathrm{mmol})$ in TFA (150 mL, 1900 $\mathrm{mmol}$ ) was stirred at room temperature for $2 \mathrm{~h}$. After $2 \mathrm{~h}$ the reaction mixture was concentrated under reduced pressure and diluted with EtOAc $(1 \mathrm{~L})$. The solution was washed with saturated $\mathrm{NaHCO}_{3}(500$ 
$\mathrm{mL})$, water $(1 \mathrm{~L})$, brine $(300 \mathrm{~mL})$ and was dried over anhydrous $\mathrm{Na}_{2} \mathrm{SO}_{4}$. After filtration, the filtrate was concentrated under reduced pressure. The residue was purified by silica gel chromatography (Petroleum ether $/$ EtOAc $=5 / 1$ to $2 / 1)$ to afford ethyl 2-(6-nitropyridin-3-yl)acetate $(55 \mathrm{~g}, 96 \%)$. MS (ESI) calc'd for $\mathrm{C}_{9} \mathrm{H}_{10} \mathrm{~N}_{2} \mathrm{O}_{4}[\mathrm{M}+\mathrm{H}]^{+}, 211$; found, 211.

Step 3: Preparation of ethyl 1-(6-nitropyridin-3-yl)cyclobutanecarboxylate

To a solution of ethyl 2-(6-nitropyridin-3-yl)acetate $(33 \mathrm{~g}, 160 \mathrm{mmol})$ in DMF (150 mL) was added $\mathrm{NaH}$ (13 g, $330 \mathrm{mmol})\left(60 \%\right.$ in oil) at $0{ }^{\circ} \mathrm{C}$. The reaction mixture was stirred for $15 \mathrm{~min}$ while warming to room temperature. After 15 minutes the reaction mixture was cooled to $0{ }^{\circ} \mathrm{C}$ and 1,3-diiodopropane (37 $\mathrm{mL}, 330 \mathrm{mmol}$ ) was added. After stirring at $0{ }^{\circ} \mathrm{C}$ for $30 \mathrm{~min}$, the reaction mixture was warmed to room temperature and was stirred for $1 \mathrm{~h}$. After $1 \mathrm{~h}$, saturated $\mathrm{NH}_{4} \mathrm{Cl}(500 \mathrm{~mL})$ was added, followed by the addition of water $(500 \mathrm{~mL})$. The reaction mixture was washed with EtOAc $(500 \mathrm{~mL} \times 3)$. The combined organics were washed with brine $(200 \mathrm{~mL})$, dried over anhydrous $\mathrm{Na}_{2} \mathrm{SO}_{4}$, filtered and concentrated under reduced pressure. The residue was purified by silica gel chromatography (Petroleum ether/EtOAc $=30 / 1$ to $20 / 1$ ) to afford ethyl 1-(6-nitropyridin-3-yl)cyclobutanecarboxylate (19 g, 45\% yield). MS (ESI) calc'd for $\mathrm{C}_{12} \mathrm{H}_{14} \mathrm{~N}_{2} \mathrm{O}_{4}[\mathrm{M}+\mathrm{H}]^{+}, 251$; found, 251 .

Step 4: Preparation of ethyl 1-(6-aminopyridin-3-yl)cyclobutane-1-carboxylate

To a stirred solution of 1-(1-(6-nitropyridin-3-yl)cyclobutyl)propan-1-one (5 g, $21 \mathrm{mmol})$ in EtOH (80 mL) and water $(8 \mathrm{~mL})$ was added iron $(5.96 \mathrm{~g}, 107 \mathrm{mmol})$ and ammonium chloride $(11.4 \mathrm{~g}, 213 \mathrm{mmol})$. The reaction was stirred at $90^{\circ} \mathrm{C}$ for $2 \mathrm{~h}$. After $2 \mathrm{~h}$ the reaction mixture was filtered through a pad of Celite. The filtrate was washed with $\mathrm{EtOH}(300 \mathrm{~mL})$ and concentrated under reduced pressure. The residue was purified by silica gel chromatography (DCM/EtOH=20/1) to afford ethyl 1-(6-aminopyridin-3yl)cyclobutanecarboxylate (4.2 g, 89\% yield). MS (ESI) calc'd for $\mathrm{C}_{12} \mathrm{H}_{16} \mathrm{~N}_{2} \mathrm{O}_{2}[\mathrm{M}+\mathrm{H}]^{+}, 221$; found, 221.

Step 5: Preparation of ethyl 1-(6-(3-chlorobenzamido)pyridin-3-yl)cyclobutane-1-carboxylate

To a vial was added 3-chlorobenzoic acid (2.2 g, 14 mmol), ethyl 1-(6-aminopyridin-3-yl)cyclobutane-1carboxylate $(3.0 \mathrm{~g}, 14 \mathrm{mmol}), \operatorname{HATU}(5.7 \mathrm{~g}, 15 \mathrm{mmol}), \operatorname{DMF}(100 \mathrm{ml})$ and DIEA $(8 \mathrm{ml}, 46 \mathrm{mmol})$. The 
mixture was stirred at room temperature for $19 \mathrm{~h}$. After $19 \mathrm{~h}$ the crude reaction mixture was concentrated under reduced pressure. The residue was purified by flash chromatography on silica (120 g, EtOAc in hexane, 0-20\%) to afford ethyl 1-(6-(3-chlorobenzamido)pyridin-3-yl)cyclobutanecarboxylate (3.1 g, 63\% yield). MS (ESI) Calc'd for $\mathrm{C}_{19} \mathrm{H}_{20} \mathrm{ClN}_{2} \mathrm{O}_{3}[\mathrm{M}+\mathrm{H}]^{+}$, 359; found, 359.

Step 6: Preparation of 1-(6-(3-chlorobenzamido)pyridin-3-yl)cyclobutane-1-carboxylic acid

To the vial containing ethyl 1-(6-(3-chlorobenzamido)pyridin-3-yl)cyclobutanecarboxylate (3.1 g, 8.6 mmol) was added ethanol $(10 \mathrm{ml}), \operatorname{THF}(30 \mathrm{ml})$ and $\mathrm{NaOH}(35 \mathrm{ml}, 35 \mathrm{mmol}, 1 \mathrm{M})$. The mixture was stirred at room temperature for $17 \mathrm{~h}$. After $17 \mathrm{~h}$ the crude reaction mixture was concentrated under reduced pressure. To the residue was added $\mathrm{HCl}(1 \mathrm{M})$ to adjust the $\mathrm{pH}$ to $\sim 4$. The crude was filtered to afford 1-(6-(3-chlorobenzamido)pyridin-3-yl)cyclobutane-1-carboxylic acid which was used without further purification. MS (ESI) Calc'd for $\mathrm{C}_{17} \mathrm{H}_{16} \mathrm{CIN}_{2} \mathrm{O}_{3}[\mathrm{M}+\mathrm{H}]^{+}, 331$; found, 331 .

Step 7: Preparation of 3-chloro-N-(5-(1-((4-fluorophenyl)carbamoyl)cyclobutyl)pyridin-2-yl)benzamide

(9)

To a vial equipped with a stir bar was added 1-(6-(3-chlorobenzamido)pyridin-3-yl)cyclobutanecarboxylic acid (20 mg, $0.060 \mathrm{mmol}$ ), 4-fluoroaniline ( $28 \mathrm{mg}, 0.252 \mathrm{mmol}$ ), HATU (34.5 mg, $0.091 \mathrm{mmol}$ ), DMF (500 $\mu \mathrm{l})$ and DIEA $(40 \mu \mathrm{l}, 0.229 \mathrm{mmol})$. The mixture was stirred at rt for $18 \mathrm{~h}$. After 18 hours the mixture was filtered and purified via mass triggered reversed phase HPLC, ACN/water, TFA to afford 9 (11.7 mg, $0.022 \mathrm{mmol}, 36.0 \%$ yield) as a white solid. MS (ESI) calc'd for C23H19CIFN3O2 [M+H]+, 424; found, 424. ${ }^{1} \mathrm{H}$ NMR (600 MHz, DMSO) $\delta 10.98(\mathrm{~s}, 1 \mathrm{H}) 9.58(\mathrm{~s}, 1 \mathrm{H}), 8.48(\mathrm{~d}, 1 \mathrm{H}), 8.16(\mathrm{~d}, 1 \mathrm{H}), 8.06(\mathrm{t}, 1 \mathrm{H}), 7.97$ $(\mathrm{m}, 1 \mathrm{H}), 7.91(\mathrm{~m}, 1 \mathrm{H}), 7.66(\mathrm{~m}, 1 \mathrm{H}), 7.61(\mathrm{~m}, 2 \mathrm{H}), 7.54(\mathrm{t}, 1 \mathrm{H}), 7.11(\mathrm{~m}, 2 \mathrm{H}), 2.85(\mathrm{~m}, 2 \mathrm{H}), 2.52(\mathrm{~m}, 2 \mathrm{H})$, 1.88 (m, 2H). ${ }^{13} \mathrm{C}$ NMR (151 MHz, DMSO) $\delta 173.42,164.54,158.90,157.31,150.47,145.60,136.05$, $135.87,135.48,135.40,133.17,131.70,130.31,127.83,126.72$, 121.79, 115.12, 114.39, 51.57, 31.82, 15.76. (observed complexity due to C-F splitting).

\section{Compound 10: 3-chloro-N-(2-(1-((4-fluorophenyl)carbamoyl)cyclobutyl)pyrimidin-5-yl)benzamide}




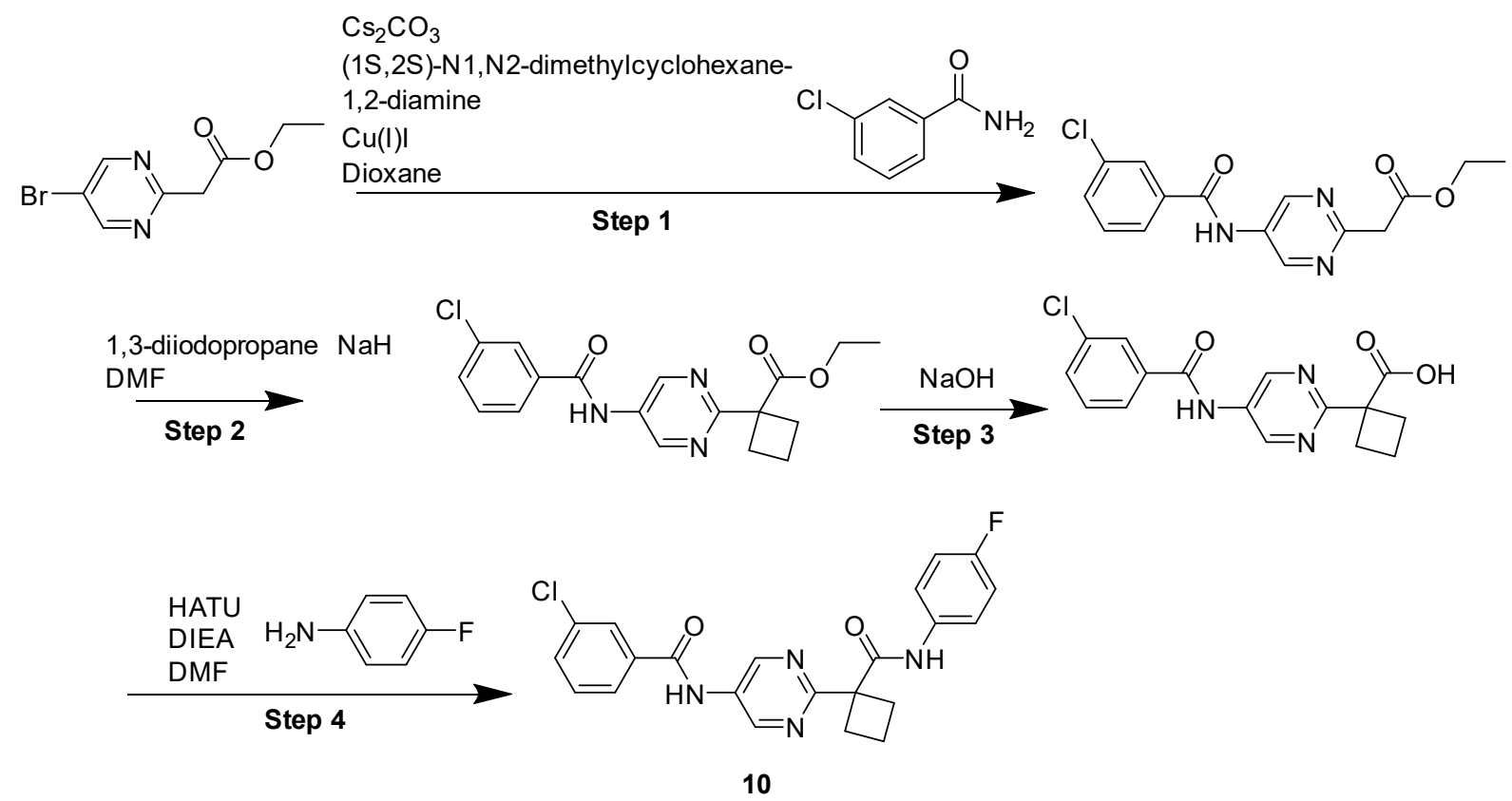

Step 1: Preparation of ethyl 2-(5-(3-chlorobenzamido)pyrimidin-2-yl)acetate

To a vial equipped with a stir bar was added ethyl 2-(5-bromopyrimidin-2-yl)acetate (500 mg, 2.04 mmol), cesium carbonate (1000 mg, $6.1 \mathrm{mmol}$ ), 3-chlorobenzamide (310 mg, $2.0 \mathrm{mmol}),(1 S, 2 S)-N 1, N 2$ dimethylcyclohexane-1,2-diamine $(58 \mathrm{mg}, 0.41 \mathrm{mmol})$, and dioxane $(10 \mathrm{ml})$. The reaction mixture was purged with nitrogen, and copper $(\mathrm{l})$ iodide $(39 \mathrm{mg}, 0.20 \mathrm{mmol})$ was added. The reaction mixture was purged with nitrogen for $5 \mathrm{~min}$, then sealed and heated to $110^{\circ} \mathrm{C}$ for $19 \mathrm{~h}$. After $19 \mathrm{~h}$ the crude reaction mixture was washed with EtOAc $(100 \mathrm{ml} \times 3)$ and saturated $\mathrm{NaHCO}_{3}$. The combined organics were dried over anhydrous magnesium sulfate, filtered, and concentrated under reduced pressure. The residue was purified by column chromatography on silica (0-100\% EtOAc/hexanes) to afford ethyl 2-(5-(3chlorobenzamido)pyrimidin-2-yl)acetate (203 mg, 31\% yield). MS ESI calc'd. for $\mathrm{C}_{15} \mathrm{H}_{14} \mathrm{ClN}_{3} \mathrm{O}_{3}[\mathrm{M}+\mathrm{H}]^{+}$ 320 , found 320 .

Step 2: Preparation of ethyl 1-(5-(3-chlorobenzamido)pyrimidin-2-yl)cyclobutane-1-carboxylate

To a vial equipped with a stir bar was added ethyl 2-(5-(3-chlorobenzamido)pyrimidin-2-yl)acetate (200 $\mathrm{mg}, 0.64 \mathrm{mmol})$ and DMF $(6.3 \mathrm{ml})$. The solution was cooled to $0{ }^{\circ} \mathrm{C}$ with an ice bath. $\mathrm{NaH}(53 \mathrm{mg}, 1.3$ $\mathrm{mmol}$ ) (60\% mineral oil) was added slowly and cautiously. The resulting mixture was allowed to warm to rt and was stirred for $15 \mathrm{~min}$. After $15 \mathrm{~min}$ the mixture was cooled to $0{ }^{\circ} \mathrm{C}$ and 1,3-diiodopropane $(150 \mu \mathrm{l}, 1.3 \mathrm{mmol})$ was added drop wise. The resulting mixture was allowed to stir at $0{ }^{\circ} \mathrm{C}$ for about 60 
$\min$. After $60 \mathrm{~min}$ the reaction mixture was cooled to $0{ }^{\circ} \mathrm{C}$ and water was added. The reaction mixture was extracted with DCM $(3 \times 50 \mathrm{ml})$. The resulting organic layers were combined, dried over magnesium sulfate, filtered, and concentrated under reduced pressure. The residue was purified by column chromatography on silica (0-100\% EtOAc/hexanes) to afford ethyl 1-(5-(3-chlorobenzamido)pyrimidin-2yl)cyclobutane-1-carboxylate (32 mg, 14\% yield). MS ESI calc'd. for $\mathrm{C}_{18} \mathrm{H}_{18} \mathrm{CIN}_{3} \mathrm{O}_{3}[\mathrm{M}+\mathrm{H}]^{+} 360$, found 360 .

Step 3: Preparation of 1-(5-(3-chlorobenzamido)pyrimidin-2-yl)cyclobutane-1-carboxylic acid

To a vial equipped with a stir bar was added ethyl 1-(5-(3-chlorobenzamido)pyrimidin-2-

yl)cyclobutanecarboxylate (32 mg, $0.088 \mathrm{mmol})$, ethanol $(440 \mu \mathrm{l}) / \mathrm{THF}(440 \mu \mathrm{l})$, and $\mathrm{NaOH}(180 \mu \mathrm{l}, 0.18$ $\mathrm{mmol})$. The reaction mixture was stirred at RT for $19 \mathrm{~h}$. After $19 \mathrm{~h}$ the reaction mixture was concentrated under reduced pressure. The residue was dissolved in EtOAc and $\mathrm{HCl}(1 \mathrm{M})$ was added dropwise to adjust the $\mathrm{pH}$ to $\sim 3$. The residue was concentrated under reduced pressure to afford 1-(5(3-chlorobenzamido)pyrimidin-2-yl)cyclobutane-1-carboxylic acid as an $\mathrm{HCl}$ salt which was used without further purification. MS ESI calc'd. for $\mathrm{C}_{16} \mathrm{H}_{14} \mathrm{CIN}_{3} \mathrm{O}_{3}[\mathrm{M}+\mathrm{H}]^{+} 332$, found 332 .

Step 4: Preparation of 3-chloro-N-(2-(1-((4-fluorophenyl)carbamoyl)cyclobutyl)pyrimidin-5-yl)benzamide $\underline{(10)}$

To a vial equipped with a stir bar was added 1-(5-(3-chlorobenzamido)pyrimidin-2-

yl)cyclobutanecarboxylic acid, $\mathrm{HCl}(32 \mathrm{mg}, 0.087 \mathrm{mmol}$ ), HATU (43 mg, $0.11 \mathrm{mmol}$ ), and DMF (440 $\mu \mathrm{l})$. The reaction mixture was stirred for $5 \mathrm{~min}$. After $5 \mathrm{~min}$ the 4 -fluoroaniline $(8.2 \mu \mathrm{l}, 0.087 \mathrm{mmol})$ was added, followed by DIEA ( $91 \mu \mathrm{l}, 0.52 \mathrm{mmol})$. The reaction mixture was stirred for 5.5 hours at room temperature. After $5.5 \mathrm{~h}$ the reaction mixture was dissolved in $500 \mu \mathrm{L}$ DMSO, filtered, purified via mass triggered reversed phase HPLC, ACN/water, TFA to afford 10 (2.7 mg, $5.01 \mu \mathrm{mol}, 5.8 \%$ yield). MS ESI calc'd. for $\mathrm{C}_{23} \mathrm{H}_{19} \mathrm{ClFN}_{3} \mathrm{O}_{2}[\mathrm{M}+\mathrm{H}]^{+} 425$, found 425. ${ }^{1} \mathrm{H}$ NMR (400 MHz, DMSO-d $\left.d_{6}\right) \delta 10.77(\mathrm{~s}, 1 \mathrm{H}), 10.33$ (s, 1H), $9.16(\mathrm{~s}, 2 \mathrm{H}), 8.08(\mathrm{~s}, 1 \mathrm{H}), 8.01-7.94(\mathrm{~m}, 1 \mathrm{H}), 7.78-7.71(\mathrm{~m}, 1 \mathrm{H}), 7.70-7.61(\mathrm{~m}, 2 \mathrm{H}), 7.21-7.11$ $(\mathrm{m}, 2 \mathrm{H}), 5.94-5.81(\mathrm{~m}, 1 \mathrm{H}), 5.14(\mathrm{~d}, J=17.0 \mathrm{~Hz}, 1 \mathrm{H}), 5.03(\mathrm{~d}, J=9.5 \mathrm{~Hz}, 1 \mathrm{H}), 4.19-4.12(\mathrm{~m}, 1 \mathrm{H}), 2.94-$ $2.80(\mathrm{~m}, 3 \mathrm{H})$.

\section{Compound 11: 3-(4-(3-chlorobenzamido)phenyl)-N-(4-fluorophenyl)oxetane-3-carboxamide}




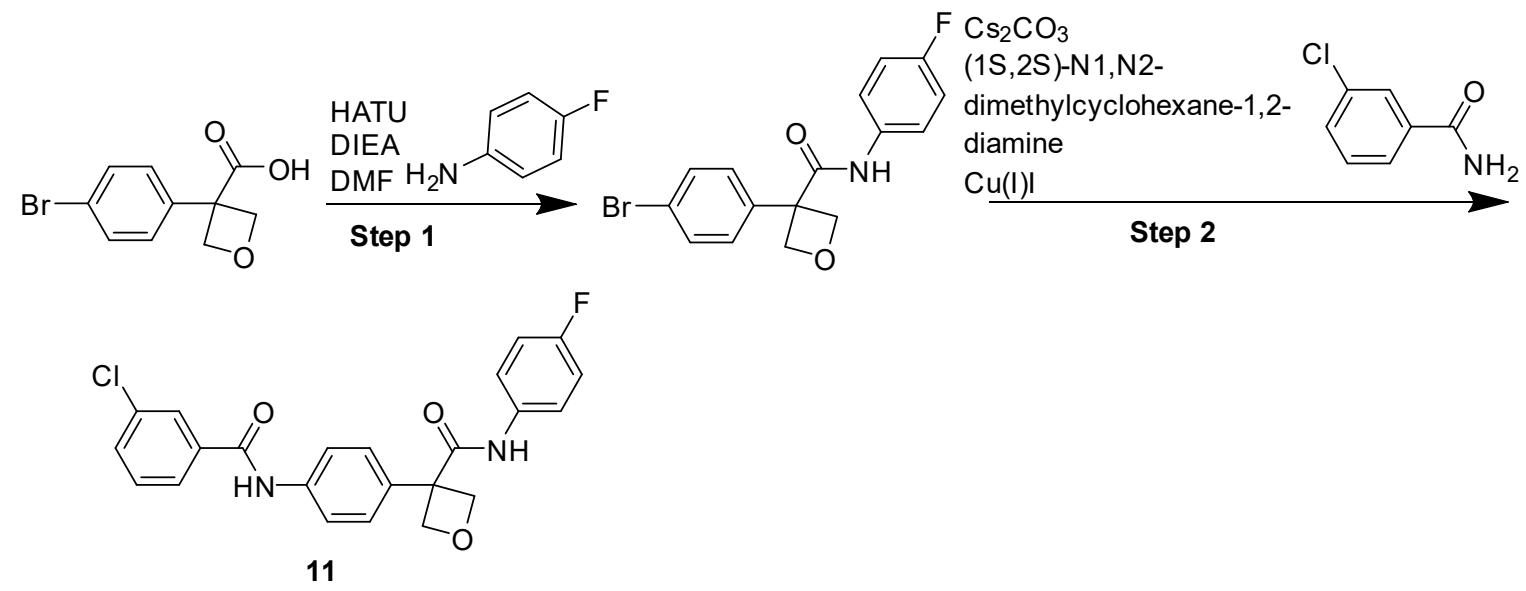

Step 1: Preparation of 3-(4-bromophenyl)-N-(4-fluorophenyl)oxetane-3-carboxamide

To a vial containing 3-(4-bromophenyl)oxetane-3-carboxylic acid ( $810 \mathrm{mg}, 3.2 \mathrm{mmol}$ ) and HATU (1.6 g, $4.1 \mathrm{mmol}$ ) was added DMF (12 ml). The reaction mixture was allowed to stir at room temperature for 5 min, after which 4-fluoroaniline ( $350 \mathrm{mg}, 3.2 \mathrm{mmol}$ ) was added as a solution in DMF (3.9 ml). Lastly DIPEA ( $2.5 \mathrm{ml}, 14 \mathrm{mmol}$ ) was added and the reaction mixture was stirred at room temperature for $18 \mathrm{~h}$. After $18 \mathrm{~h}$ the crude reaction mixture was washed with EtOAc and saturated $\mathrm{NaHCO}_{3}$. The combined organic layers were dried over anhydrous magnesium sulfate, filtered, and concentrated under reduced pressure to afford 3-(4-bromophenyl)-N-(4-fluorophenyl)oxetane-3-carboxamide which was used in the next step without further purification. MS ESI calc'd. for $\mathrm{C}_{16} \mathrm{H}_{13} \mathrm{BrFNO}_{2}[\mathrm{M}+\mathrm{H}]^{+} 350$, found 350 .

Step 2: 3-(4-(3-chlorobenzamido)phenyl)-N-(4-fluorophenyl)oxetane-3-carboxamide (11)

To a vial equipped with a stir bar was added 3-(4-bromophenyl)-N-(4-fluorophenyl)oxetane-3carboxamide (100 mg, $0.29 \mathrm{mmol}$ ), cesium carbonate ( $280 \mathrm{mg}, 0.86 \mathrm{mmol}$ ), 3-chlorobenzamide (44 mg, $0.28 \mathrm{mmol}),(1 S, 2 S)-N 1, N 2$-dimethylcyclohexane-1,2-diamine $(8.1 \mathrm{mg}, 0.057 \mathrm{mmol})$, and dioxane (1400 $\mu l)$. The vial was purged with nitrogen, and $\mathrm{Cu}(\mathrm{l}) \mathrm{I}(5.4 \mathrm{mg}, 0.029 \mathrm{mmol})$ was added. The vial was purged with nitrogen for $3 \mathrm{~min}$ and sealed and heated to $110{ }^{\circ} \mathrm{C}$ for $24 \mathrm{~h}$. After $24 \mathrm{~h}$ the crude reaction mixture was dissolved in methanol and filtered over celite. The resulting residue was concentrated under reduced pressure. The residue was dissolved in DMSO $(1.6 \mathrm{ml})$, filtered, and purified via mass triggered reversed phase HPLC, ACN/water, TFA to afford 11 (29 mg, 0.068 mmol, 24\% yield). MS ESI calc'd. for $\mathrm{C}_{23} \mathrm{H}_{18} \mathrm{ClFN}_{2} \mathrm{O}_{3}[\mathrm{M}+\mathrm{H}]^{+} 425$, found 425. ${ }^{1} \mathrm{H}$ NMR (499 MHz, DMSO- $\left.d_{6}\right) \delta 10.46(\mathrm{~s}, 1 \mathrm{H}), 9.99(\mathrm{~s}, 1 \mathrm{H}), 8.04$ 
(s, 1H), $7.95(\mathrm{~d}, J=7.7 \mathrm{~Hz}, 1 \mathrm{H}), 7.84(\mathrm{~d}, J=8.5 \mathrm{~Hz}, 2 \mathrm{H}), 7.71(\mathrm{~d}, J=7.9 \mathrm{~Hz}, 1 \mathrm{H}), 7.69-7.63(\mathrm{~m}, 2 \mathrm{H}), 7.61$ $(\mathrm{t}, J=7.9 \mathrm{~Hz}, 1 \mathrm{H}), 7.51(\mathrm{~d}, J=8.5 \mathrm{~Hz}, 2 \mathrm{H}), 7.19(\mathrm{t}, J=8.8 \mathrm{~Hz}, 2 \mathrm{H}), 5.22(\mathrm{~d}, J=6.4 \mathrm{~Hz}, 2 \mathrm{H}), 4.91$ (d, J = 6.4 $\mathrm{Hz}, 2 \mathrm{H}) .{ }^{13} \mathrm{C}$ NMR $(151 \mathrm{MHz}$, DMSO) $\delta 171.53,164.01,157.43,137.99,136.74,136.35,135.17,133.21$, $131.45,130.43,127.38,126.49,126.26,121.59,120.61,115.25,79.12,53.96$.

Compound 12: 3-chloro-N-(4-((1s,3s)-1-((4-fluorophenyl)carbamoyl)-3-hydroxycyclobutyl)phenyl)benzamide

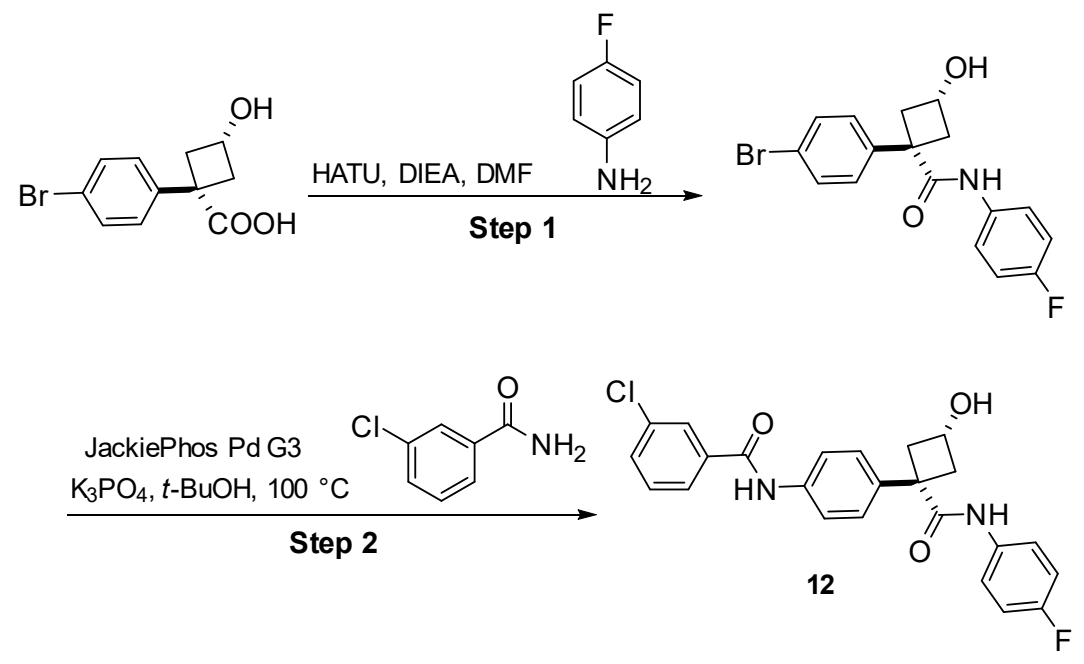

Step 1: Preparation of (cis)-1-(4-bromophenyl)-N-(4-fluorophenyl)-3-hydroxycyclobutane-1-carboxamide

To a vial was added (cis)-1-(4-bromophenyl)-3-hydroxycyclobutanecarboxylic acid (100 mg, $0.37 \mathrm{mmol}$ ),

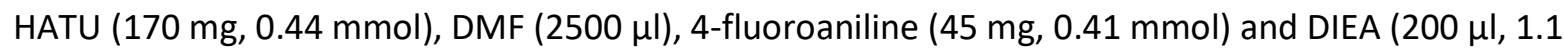
mmol). The mixture was stirred at RT for $18 \mathrm{~h}$. After $18 \mathrm{~h}$ the solvent was concentrated under reduced pressure. The residue was purified by flash chromatography on silica (12g, EtOAc in hexane, 0-80\%, 10 $\mathrm{CV}$ ) to afford (cis)-1-(4-bromophenyl)-N-(4-fluorophenyl)-3-hydroxycyclobutanecarboxamide. MS (ESI) Calc'd $[\mathrm{M}+\mathrm{H}]^{+}, 364$; found, 364 .

Step 2: Preparation of 3-chloro-N-(4-((cis)-1-((4-fluorophenyl)carbamoyl)-3hydroxycyclobutyl)phenyl)benzamide (12)

To a vial was added (cis)-1-(4-bromophenyl)-N-(4-fluorophenyl)-3-hydroxycyclobutanecarboxamide (39 $\mathrm{mg}, 0.11 \mathrm{mmol}$ ), 3-chlorobenzamide ( $25 \mathrm{mg}, 0.16 \mathrm{mmol}$ ), $\mathrm{K}_{3} \mathrm{PO}_{4}(70 \mathrm{mg}, 0.33 \mathrm{mmol}$ ), JackiePhos Pd G3 (12 mg, $11 \mu \mathrm{mol})$ and $t-\mathrm{BuOH}(700 \mu \mathrm{l})$. The mixture was evacuated and backfilled with $\mathrm{N}_{2}(\times 4)$, then heated at $100^{\circ} \mathrm{C}$ for $3 \mathrm{~h}$. After $3 \mathrm{~h}$ the mixture was filtered and purified via reverse phase purification, 
(purified by HPLC, eluting acetonitrile/water gradient with TFA modifier, linear gradient) to afford the desired compound 12 (13 mg, 31\% yield). MS (ESI) Calc'd MS (ESI) calc'd for C24H20CIFN2O3 [M+H]+, 439; found, 439. ${ }^{1} \mathrm{H}$ NMR (600 MHz, DMSO-d $\left.d_{6}\right) \delta 10.30(\mathrm{~s}, 1 \mathrm{H}), 9.30(\mathrm{~s}, 1 \mathrm{H}), 7.95(\mathrm{~s}, 1 \mathrm{H}), 7.86$ (d, J = 7.7 $\mathrm{Hz}, 1 \mathrm{H}), 7.70(\mathrm{~d}, J=8.4 \mathrm{~Hz}, 2 \mathrm{H}), 7.62(\mathrm{~d}, J=7.8 \mathrm{~Hz}, 1 \mathrm{H}), 7.58-7.49(\mathrm{~m}, 3 \mathrm{H}), 7.44(\mathrm{~d}, J=8.4 \mathrm{~Hz}, 2 \mathrm{H}), 7.05$ $(t, J=8.8 \mathrm{~Hz}, 2 \mathrm{H}), 3.87(\mathrm{p}, J=7.2 \mathrm{~Hz}, 1 \mathrm{H}), 3.33(\mathrm{~s}, 1 \mathrm{H}), 2.86-2.73(\mathrm{~m}, 2 \mathrm{H}), 2.54-2.43(\mathrm{~m}, 2 \mathrm{H})$.

\section{Compound 13: 3-(5-(3-chlorobenzamido)-6-methylpyridin-2-yl)-N-(4-fluorophenyl)oxetane-3-} carboxamide

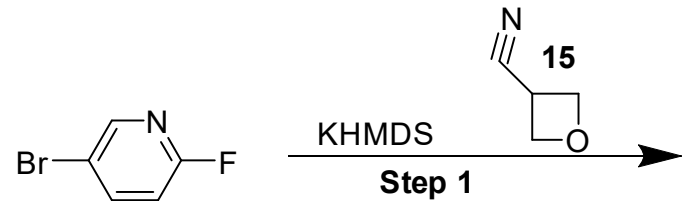

14<smiles>CC(C)(CO)c1ccc(Br)cn1</smiles>

16

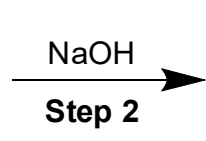

Step 2<smiles>O=C(O)C1(c2ccc(Br)cn2)COC1</smiles>

17
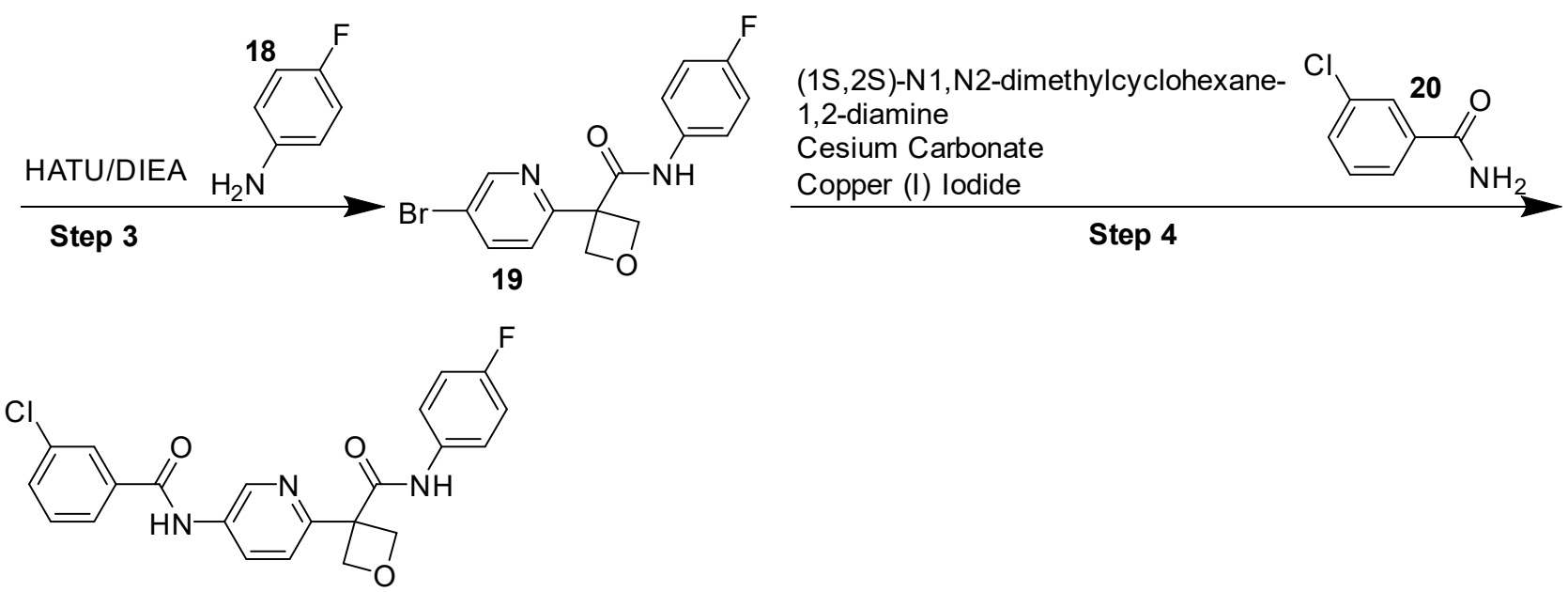

13

Step 1: Preparation of 3-(5-bromopyridin-2-yl)oxetane-3-carbonitrile (16)

To a vial equipped with a stir bar was added 5-bromo-2-fluoropyridine (14) (58.5 $\mu \mathrm{l}, 0.57 \mathrm{mmol})$, oxetane-3-carbonitrile (15) $(47 \mu \mathrm{l}, 0.63 \mathrm{mmol})$, and toluene $(2.8 \mathrm{ml})$. The reaction mixture was then cooled to $0{ }^{\circ} \mathrm{C}$ while stirring under nitrogen. KHMDS $1.0 \mathrm{M}$ in THF $(682 \mu \mathrm{l}, 0.682 \mathrm{mmol})$ was then added slowly and the reaction was stirred at $0{ }^{\circ} \mathrm{C}$. After 5 minutes the reaction was quenched by the slow addition of $\mathrm{MeOH}$. The crude reaction mixture was filtered over celite, rinsing with EtOAc. The filtrate was concentrated under reduced pressure and the residue dissolved in DCM and loaded onto a $25 \mathrm{~g}$ silica gel column. The residue was purified eluting with a gradient of $0-100 \%$ EtOAc in Hexanes to 
afford the desired product (16) (64 mg, $0.27 \mathrm{mmol}, 47 \%$ yield). MS (ESI) calc'd for $\mathrm{C}_{9} \mathrm{H}_{7} \mathrm{BrN}_{2} \mathrm{O}[\mathrm{M}+\mathrm{H}]^{+}$, 239; found, 239.

Step 2: Preparation of 3-(5-bromopyridin-2-yl)oxetane-3-carboxylic acid (17)

To a vial equipped with a stir bar was added 3-(5-bromopyridin-2-yl)oxetane-3-carbonitrile (16) (190 mg, $0.80 \mathrm{mmol}), \mathrm{NaOH}(127 \mathrm{mg}, 3.18 \mathrm{mmol})$, ethanol $(2.7 \mathrm{ml})$, and water $(1.3 \mathrm{ml})$. The vial was sealed and heated to $80^{\circ} \mathrm{C}$ for 21 hours. After 21 hours, the crude reaction mixture was concentrated under reduced pressure. The residue was dissolved in EtOAc, and $1 \mathrm{~N} \mathrm{HCl}$ (aqueous) was added dropwise to adjust the $\mathrm{pH} \sim 2$. The combined organics were dried oven washed with water, dried over magnesium sulfate, filtered, and concentrated under reduced pressure. The residue was dissolved in ACN/water, was frozen, and dried on the lyophilizer overnight. The resulting solid was used in the next reaction without further purification (184 mg, $0.713 \mathrm{mmol}, 90 \%$ yield). MS (ESI) calc'd for $\mathrm{C}_{9} \mathrm{H}_{8} \mathrm{BrNO}_{3}[\mathrm{M}+\mathrm{H}]^{+}, 258$; found, 258.

Step 3: Preparation of 3-(5-bromopyridin-2-yl)-N-(4-fluorophenyl)oxetane-3-carboxamide (19)

To a vial equipped with a stir bar was added 3-(5-bromopyridin-2-yl)oxetane-3-carboxylic acid (17) (52.3 $\mathrm{mg}, 0.203 \mathrm{mmol})$, HATU (116 mg, $0.304 \mathrm{mmol})$, and DMF (2.0 ml). 4-fluoroaniline (18) (23.04 $\mu \mathrm{l}, 0.24$ $\mathrm{mmol}$ ) was then added, followed by DIEA $(106 \mu \mathrm{l}, 0.61 \mathrm{mmol})$. The solution was stirred at room temperature for 24 hours. After 24, the crude reaction mixture was diluted with EtOAc and saturated aqueous sodium bicarbonate. The combined organic layers were separated and dried over magnesium sulfate, filtered, and concentrated under reduced pressure. The residue was then dissolved in DCM and loaded onto a $25 \mathrm{~g}$ silica gel column; eluting with a gradient of $0-100 \%$ EtOAc in hexanes to afford the desired product (19) (61 mg, 0.18 mmol, 86\% yield). MS (ESI) calc'd for $\mathrm{C}_{15} \mathrm{H}_{12} \mathrm{BrFN}_{2} \mathrm{O}_{2}[\mathrm{M}+\mathrm{H}]^{+}, 351$; found, 351.

Step 4: 3-(5-(3-chlorobenzamido)pyridin-2-yl)-N-(4-fluorophenyl)oxetane-3-carboxamide (13)

To a vial equipped with a stir bar was added 3-(5-bromopyridin-2-yl)-N-(4-fluorophenyl)oxetane-3carboxamide (19) (61.3 mg, $0.18 \mathrm{mmol}$ ), cesium carbonate (171 mg, $0.52 \mathrm{mmol}$ ), 3-chlorobenzamide (20) (26.6 mg, $0.17 \mathrm{mmol}$ ), (1S,2S)-N1,N2-dimethylcyclohexane-1,2-diamine (4.97 mg, $0.035 \mathrm{mmol}$ ), and dioxane $(3.5 \mathrm{ml})$. The reaction mixture was purged with nitrogen, and copper(I) iodide $(3.32 \mathrm{mg}, 0.017$ 
$\mathrm{mmol}$ ) was added. The reaction mixture was purged with nitrogen for 3 minutes. After 3 minutes, the vial was sealed and heated to $110^{\circ} \mathrm{C}$ for 19 hours. After 19 hours, the reaction mixture was cooled to room temperature, and was filtered over celite, rinsing with methanol. The combined organics were concentrated under reduced pressure. The residue was dissolved in EtOAc and washed with water. The combined organics were dried over magnesium sulfate, filtered, and concentrated under reduced pressure. The residue was then dissolved in DCM and loaded onto a $40 \mathrm{~g}$ column. The column was eluted with a gradient from 0 - 100\% EtOAc in hexanes to afford the desired product $13(55.4 \mathrm{mg}, 0.13$ mmol, 74.5\% yield). MS (ESI) calc'd for $\mathrm{C}_{22} \mathrm{H}_{17} \mathrm{ClFN}_{3} \mathrm{O}_{3}[\mathrm{M}+\mathrm{H}]^{+}$, 426; found, 426 . ${ }^{1} \mathrm{H} \mathrm{NMR}(500 \mathrm{MHz}$, DMSO- $\left.d_{6}\right) \delta 10.62(\mathrm{~s}, 1 \mathrm{H}), 9.99(\mathrm{~s}, 1 \mathrm{H}), 8.97(\mathrm{~d}, J=2.5 \mathrm{~Hz}, 1 \mathrm{H}), 8.23(\mathrm{dd}, J=8.6,2.5 \mathrm{~Hz}, 1 \mathrm{H}), 8.03(\mathrm{t}, J=1.9$ $\mathrm{Hz}, 1 \mathrm{H}), 7.94(\mathrm{~d}, J=8.0 \mathrm{~Hz}, 1 \mathrm{H}), 7.69(\mathrm{ddd}, J=8.1,2.2,1.1 \mathrm{~Hz}, 1 \mathrm{H}), 7.65(\mathrm{dd}, J=9.0,5.1 \mathrm{~Hz}, 2 \mathrm{H}), 7.59(\mathrm{t}, J$ $=7.9 \mathrm{~Hz}, 1 \mathrm{H}), 7.53(\mathrm{~d}, J=8.6 \mathrm{~Hz}, 1 \mathrm{H}), 7.15(\mathrm{t}, J=8.9 \mathrm{~Hz}, 2 \mathrm{H}), 5.13(\mathrm{~d}, J=6.3 \mathrm{~Hz}, 2 \mathrm{H}), 4.99(\mathrm{~d}, J=6.3 \mathrm{~Hz}$, 2H). ${ }^{13} \mathrm{C}$ NMR (151 MHz, DMSO) $\delta 173.95,163.91,157.98,139.62,137.04,135.63,133.19,131.38$, $130.41,127.34,126.46,126.18,124.19,121.58,120.37$, 114.99, 53.27, 32.04, 15.58 (observed complexity due to C-F splitting).

\section{In Vivo PK Protocol and Animal Care Statement (Table 2)}

Reference standard of the analyte was synthesized at Merck Research Laboratories and a $10 \mathrm{mM}$ stock solution was made by dissolving a suitable quantity of the standard compound in dimethyl sulfoxide (DMSO). Standard working solutions at 1 and $0.05 \mathrm{mM}$ were prepared by diluting suitable amounts of the stock solution (10 mM) with DMSO for the calibration standards (STD) and quality control (QC) samples preparation. Calibration standards and quality control samples were prepared by dispensing different volumes (ranging from 0.02 to $500 \mathrm{~nL}$ ) of the standard working solutions using the HP D300 Digital Dispenser.

Compounds were dosed as indicated in Table 2. Studies were conducted either at Charles River Laboratories or at WuXi AppTec. At WuXi, Adult Male Wistar Han rat weighing 200-300 g were purchased from Beijing Vital River Laboratory Animal Technology Co., Ltd, Beijing, China. All the animals were housed in the AAALAC accredited barrier animal facility at $20-260 \mathrm{C}, 40 \%-70 \%$ humidity and $12 \mathrm{~h}$ light/dark cycles. All the experiments were approved by Institutional Animal Care and Use Committee (IACUC) of WuXi AppTec. At Charles River Laboratories, Male Wistar Han rats, Crl:WI(Han), 6-8 weeks old, weighing 225250 g were purchased from Charles River Laboratories, International, Inc., Kingston, New York, USA. All the animals were housed in the AAALAC accredited vivarium at $20-260 \mathrm{C}, 30 \%-70 \%$ humidity and $12 \mathrm{~h}$ 
light/dark cycles. All the experiments were approved by Institutional Animal Care and Use Committee (IACUC) of Charles River Massachusetts.

Unknown samples obtained from dosed animals, calibration standards, and quality control samples were prepared for analysis employing a single step protein precipitation technique by adding 200 $\mu \mathrm{L}$ of internal standard (IS) crashing solvent to $50 \mu \mathrm{L}$ aliquots of individual samples. The internal standard solution is prepared by diluting $1 \mathrm{~mL}$ ampoule of Cerilliant IS MIX (Diclofenac $200 \mu \mathrm{M}$, Labetalol $200 \mu \mathrm{M}$, and Imipramine $200 \mu \mathrm{M}$ ) in $1 \mathrm{~L}$ of acetonitrile. Samples were mixed by vortexing for homogeneity for 2 min and centrifuged at $3500 \mathrm{rpm}$ for $5 \mathrm{~min}$. The supernatant (200 $\mu \mathrm{L})$ was transferred into a 96 -well plate and injected into the LC-MS/MS for analysis.

Chromatography was performed on a Waters Acquity HSS T3 $(2.1 \mathrm{~mm} \times 50 \mathrm{~mm}, 1.8 \mu \mathrm{m})$ column at room temperature with an injection volume of $5 \mu \mathrm{L}$. The mobile phase consisting of a solvent $\mathrm{A}(0.1 \%$ formic acid in water) and solvent B (0.1\% formic acid in acetonitrile) was delivered at a flow rate of 750 $\mu \mathrm{L} / \mathrm{min}$. The $\mathrm{LC}$ gradient started from 95/5 (A/B) and changed to 5/95 (A/B) from 0.25 to $1.75 \mathrm{~min}$ (ramp) and remaining constant to this ratio for $0.42 \mathrm{~min}$ (step). The gradient decreased to 95/5 (A/B) at $2.17 \mathrm{~min}$ (step) remaining constant to this ratio for $1.0 \mathrm{~min}$.

Detection was carried out using a triple quadrupole tandem mass spectrometer (API 6500, Applied Biosystems) equipped with an electrospray interface (ESI). lons were created in the positive ion mode setting the sprayer voltage at $5.0 \mathrm{kV}$ and the ion source temperature at $500^{\circ} \mathrm{C}$. The common parameters and the nitrogen flow values for nebulizer gas (Gas 1), auxiliary gas (Gas 2), curtain gas and the gas for collision-activated dissociation (CAD) were set at 60,60,35, and 5, respectively. The Analyst 1.6.2 software (Applied Biosystems) was used to control the MS-MS system and MultiQuant 3.0.1 for data analyses.

\section{Prediction of Human Pharmacokinetic Parameters and Efficacious Dose for Compound 3} (Table 2)

Preclinical concentration-time data from rat was fit to a two compartment pharmacokinetic model (WNL5 Classic Model 6.3; Phoenix 64 (Build 6.3.0.395)) to obtain the mean, standard error and correlation matrix of the clearance and volume of distribution in each of these species. As Compound 3 was assumed to be cleared primarily by CYP-mediated oxidative metabolism in rat (data not shown), the human clearance and volume of distribution parameters were predicted using single species allometric scaling with fixed allometric exponents of 0.75 and 1 , respectively. The prediction of oral absorption 
was achieved using the fafgfh method, where fa was estimated using a permeability limited model, $\mathrm{fg}$ was fixed to 0.5 , and fh was set to the ratio of the predicted human blood clearance and human hepatic blood flow. Human pharmacokinetics were assumed to follow the two compartment model profile observed in preclinical species.

Steady-state trough coverage of the projected human IC 75 $_{75}$ for IDO1 $(0.08 \mu \mathrm{M})$ from in vitro whole blood assays following a simulated once daily oral administration (QD) to steady state was assumed to be the required efficacious dose. The human dose was predicted using an internal web-based application employing R script which enables incorporation and visualization of the impact of experimental uncertainty on the predicted dose and PK. Uncertainty estimates were obtained using Monte Carlo simulation (1000 simulations) and used to generate the human concentration-time profile while sampling from these parameter distributions, resulting in a median predicted profile where Ctrough $=$ IDO1 IC 75 at steady state with associated confidence intervals.

Human dose predictions for compounds 9,11 , and 13 were determined in a similar manner.

\section{Supporting Figures}

Off-target Screening Results for Compound 9 (Figure S-1) 
Figure S-1

\section{Experimental Results}

\begin{tabular}{|c|c|c|c|c|c|c|c|c|c|c|}
\hline Cat \# & Assay Name & Batch $^{*}$ & Spec, & Rep. & Conc, & $\%$ Inh, & $\mid \mathrm{C}_{50^{*}}$ & $K_{i}$ & $\mathrm{n}_{\mathrm{H}}$ & $\mathbf{R}$ \\
\hline 104010 & Cholinesterase, Acetyl, ACES & 400114 & hum & 1 & $10 \mu \mathrm{M}$ & 7 & & & & \\
\hline 116020 & Cyclooxygenase COX-1 & 400259 & hum & 1 & $10 \mu \mathrm{M}$ & 6 & & & & \\
\hline 118010 & Cyclooxygenase COX-2 & 400260 & hum & 1 & $10 \mu \mathrm{M}$ & -27 & & & & 1 \\
\hline 140010 & Monoamine Oxidase MAO-A & 400141 & hum & 1 & $10 \mu \mathrm{M}$ & 2 & & & & \\
\hline 140120 & Monoamine Oxidase MAO-B & 400142 & hum & 1 & $10 \mu \mathrm{M}$ & 23 & & & & \\
\hline 163500 & Peptidase, CASPB (Caspase 8) & 400038 & hum & 1 & $10 \mu \mathrm{M}$ & -2 & & & & \\
\hline 163600 & Peptidase, CASP9 (Caspase 9) & 400039 & hum & 1 & $10 \mu \mathrm{M}$ & -14 & & & & \\
\hline 112510 & Peptidase, CTSG (Cathepsin G) & 400006 & hum & 1 & $10 \mu \mathrm{M}$ & -3 & & & & \\
\hline 152000 & Phosphodiesterase PDE3 & 400089 & hum & 1 & $10 \mu \mathrm{M}$ & 19 & & & & \\
\hline 176610 & $\begin{array}{l}\text { Protein Serine/Threonine Kinase, MAPK14 } \\
\text { (038a) }\end{array}$ & 400086 & hum & 1 & $10 \mu \mathrm{M}$ & -15 & & & & \\
\hline 171000 & $\begin{array}{l}\text { Protein Serine/Threonine Kinase, MAPK3 } \\
\text { (ERK1) }\end{array}$ & 400082 & hum & 1 & $10 \mu \mathrm{M}$ & 0 & & & & \\
\hline 171315 & Protein Serine/Threonine Kinase, MARK3 & 400083 & hum & 1 & $10 \mu \mathrm{M}$ & 5 & & & & \\
\hline 178010 & $\begin{array}{l}\text { Protein Serine/Threonine Kinase, PKC, Non- } \\
\text { Selective }\end{array}$ & -400088 & rat & 1 & $10 \mu \mathrm{M}$ & 26 & & & & \\
\hline 177010 & $\begin{array}{l}\text { Protein Serine/Threonine Kinase, PRKACA } \\
\text { (PKA) }\end{array}$ & 400087 & hum & 1 & $10 \mu \mathrm{M}$ & 4 & & & & \\
\hline 170020 & Protein Tyrosine Kinase, EGF Receptor & 400081 & hum & 1 & $10 \mu \mathrm{M}$ & -24 & & & & \\
\hline 174990 & Protein Tyrosine Kinase, Insulin Receptor & 400084 & hum & 1 & $10 \mu \mathrm{M}$ & -21 & & & & \\
\hline 195000 & Tyrosine Hydroxylase & 400143 & rat & 1 & $10 \mu \mathrm{M}$ & -9 & & & & \\
\hline 200510 & Adenosine $\mathrm{A}_{1}$ & 400072 & hum & 1 & $10 \mu \mathrm{M}$ & 21 & & & & \\
\hline 200610 & Adenosine $A_{2 A}$ & 400072 & hum & 1 & $10 \mu \mathrm{M}$ & 24 & & & & \\
\hline 203100 & Adrenergic $a_{1 A}$ & 400044 & rat & 1 & $10 \mu \mathrm{M}$ & 33 & & & & \\
\hline 203200 & Adrenergic $a_{18}$ & 400043 & rat & 1 & $10 \mu \mathrm{M}$ & 27 & & & & \\
\hline 203400 & Adrenergic $a_{10}$ & 400100 & hum & 1 & $10 \mu \mathrm{M}$ & 4 & & & & \\
\hline 203630 & Adrenergic $a_{2 s}$ & 400045 & hum & 1 & $10 \mu \mathrm{M}$ & 28 & & & & \\
\hline 203710 & Adrenergic $\alpha_{23}$ & 400112 & hum & 1 & $10 \mu \mathrm{M}$ & 2 & & & & \\
\hline 203810 & Adrenergic $a_{20}$ & 400045 & hum & 1 & $10 \mu \mathrm{M}$ & 21 & & & & \\
\hline 204010 & Adrenergic $\beta_{1}$ & 400076 & hum & 1 & $10 \mu \mathrm{M}$ & 10 & & & & \\
\hline 204110 & Adrenergic $\beta_{2}$ & 400070 & hum & 1 & $10 \mu \mathrm{M}$ & 37 & & & & \\
\hline 204200 & Adrenergic $\beta_{3}$ & 400113 & hum & 1 & $10 \mu \mathrm{M}$ & 31 & & & & \\
\hline 206000 & Androgen (Testosterone) & 400080 & hum & 1 & $10 \mu \mathrm{M}$ & 21 & & & & \\
\hline 210030 & Angiotensin AT1 & 400164 & hum & 1 & $10 \mu \mathrm{M}$ & 44 & & & & \\
\hline 211000 & Atrial Natriuretic Factor (ANF) & 400176 & $g p$ & 1 & $10 \mu \mathrm{M}$ & 1 & & & & \\
\hline 212510 & Bradykinin B: & 400101 & hum & 1 & $10 \mu \mathrm{M}$ & 8 & & & & \\
\hline \multicolumn{11}{|c|}{$\begin{array}{l}\text { Note: Items meeting criteria for significance ( } 250 \% \text { stimulation or inhibition) are highlighted. } \\
\text { Batch: Represents compounds tested concurrently in the same assay(s). } \\
\text { g }=\text { Guinea pig, ham=Hamster, hum=Human } \\
\mathrm{R}=\text { See Remarks (if any) at end of this section. }\end{array}$} \\
\hline \multicolumn{11}{|c|}{ Merck Sharp \&. Dohme Corp } \\
\hline
\end{tabular}




\section{Experimental Results}

\begin{tabular}{|c|c|c|c|c|c|c|c|c|c|c|}
\hline Cat \# & Assay Name & Batch* & Spec. & Rep. & Conc. & $\%$ Inh. & $\mid C_{50} *$ & $K_{i}$ & $\mathrm{n}_{\mathrm{H}}$ & $\mathbf{R}$ \\
\hline 217030 & Cannabinoid $\mathrm{CB}_{1}$ & 400041 & hum & 1 & $10 \mu \mathrm{M}$ & 33 & & & & \\
\hline 217100 & Cannabinoid $\mathrm{CB}_{2}$ & 400098 & hum & 1 & $10 \mu \mathrm{M}$ & 36 & & & & \\
\hline 217510 & Chemokine CCR1 & 400074 & hum & 1 & $10 \mu \mathrm{M}$ & -5 & & & & \\
\hline 244500 & Chemokine CXCR2 (IL-sRs) & 400150 & hum & 1 & $10 \mu \mathrm{M}$ & 1 & & & & \\
\hline 244550 & Chemokine CXCR4 & 400154 & hum & 1 & $10 \mu \mathrm{M}$ & 0 & & & & \\
\hline 218020 & Cholecystokinin $\mathrm{CCK}_{1}\left(\mathrm{CCK}_{n}\right)$ & 400162 & hum & 1 & $10 \mu \mathrm{M}$ & 43 & & & & \\
\hline 218130 & Cholecystokinin $\mathrm{CCK}_{2}\left(\mathrm{CCK}_{3}\right)$ & 400074 & hum & 1 & $10 \mu \mathrm{M}$ & 32 & & & & \\
\hline 219150 & Corticotropin Releasing Factor CRF, & 400058 & hum & 1 & $10 \mu \mathrm{M}$ & 6 & & & & \\
\hline 299003 & $\mathrm{CysLT}_{2}\left(\mathrm{LTC} \mathrm{C}_{4}\right)$ & 400206 & hum & 1 & $10 \mu \mathrm{M}$ & 6 & & & & \\
\hline 219500 & Dopamine $D_{1}$ & 400115 & hum & 1 & $10 \mu \mathrm{M}$ & 3 & & & & \\
\hline 219700 & Dopamine $\mathrm{D}_{28}$ & 400079 & hum & 1 & $10 \mu \mathrm{M}$ & 35 & & & & \\
\hline 224010 & Endothelin $\mathrm{ET}$. & 400073 & hum & 1 & $10 \mu \mathrm{M}$ & -9 & & & & \\
\hline 224110 & Endothelin ETs & 400102 & hum & 1 & $10 \mu \mathrm{M}$ & 3 & & & & \\
\hline 226010 & Estrogen ERa & 400031 & hum & 1 & $10 \mu \mathrm{M}$ & -3 & & & & \\
\hline 226810 & GABA, Chloride Channel, TBOB & 400319 & rat & 1 & $10 \mu \mathrm{M}$ & 25 & & & & \\
\hline 226630 & GABA, Ro-15-1788, Hippocampus & 400032 & rat & 1 & $10 \mu \mathrm{M}$ & 17 & & & & \\
\hline 228510 & $\mathrm{GABA}_{3}$, Non-Selective & 400346 & rat & 1 & $10 \mu \mathrm{M}$ & -2 & & & & \\
\hline 232030 & Glucocorticoid & 400069 & hum & 1 & $10 \mu \mathrm{M}$ & 13 & & & & \\
\hline 237000 & Glutamate, Metabotropic, mGlus & 400171 & hum & 1 & $10 \mu \mathrm{M}$ & 14 & & & & \\
\hline 232810 & Glutamate, NMDA, Agonism & 400103 & rat & 1 & $10 \mu \mathrm{M}$ & 4 & & & & \\
\hline 232910 & Glutamate, NMDA, Gycine & 400103 & rat & 1 & $10 \mu \mathrm{M}$ & 22 & & & & \\
\hline 233000 & Glutamate, NMDA, Phencyclidine & 400347 & rat & 1 & $10 \mu \mathrm{M}$ & 5 & & & & \\
\hline 234000 & Glutamate, NMDA, Polyamine & 400198 & rat & 1 & $10 \mu \mathrm{M}$ & 20 & & & & \\
\hline 239000 & Glycine, Strychnine-Sensitive & 400093 & rat & 1 & $10 \mu \mathrm{M}$ & 17 & & & & \\
\hline 239610 & Histamine $\mathrm{H}_{1}$ & 400046 & hum & 1 & $10 \mu \mathrm{M}$ & 21 & & & & \\
\hline 239710 & Histamine $\mathrm{H}_{2}$ & 400076 & hum & 1 & $10 \mu \mathrm{M}$ & -8 & & & & \\
\hline 239820 & Histamine $\mathrm{H}_{2}$ & 400104 & hum & 1 & $10 \mu \mathrm{M}$ & 6 & & & & \\
\hline 239900 & Histamine $\mathrm{H}_{4}$ & 400037 & hum & 1 & $10 \mu \mathrm{M}$ & 23 & & & & \\
\hline 299004 & $\mathbb{P}(\mathrm{PG} \mid 2)$ & 400049 & hum & 1 & $10 \mu \mathrm{M}$ & 28 & & & & \\
\hline 251010 & $\begin{array}{l}\text { Melanin-Concentrating Hormone MCH1 } \\
\text { (SLC1) }\end{array}$ & 400067 & hum & 1 & $10 \mu \mathrm{M}$ & 0 & & & & \\
\hline 251100 & Melanocortin $\mathrm{MC}_{1}$ & 400034 & hum & 1 & $10 \mu \mathrm{M}$ & 9 & & & & \\
\hline 251300 & Melanocortin $\mathrm{MC}_{3}$ & 400107 & hum & 1 & $10 \mu \mathrm{M}$ & 5 & & & & \\
\hline 251350 & Melanocortin $\mathrm{MC}_{4}$ & 400034 & hum & 1 & $10 \mu \mathrm{M}$ & -2 & & & & \\
\hline 251400 & Melanocortin $\mathrm{MC}_{6}$ & 400107 & hum & 1 & $10 \mu \mathrm{M}$ & 11 & & & & \\
\hline 252610 & Muscarinic M & 400077 & hum & 1 & $10 \mu \mathrm{M}$ & 10 & & & & \\
\hline
\end{tabular}

Note: Items meeting criteria for significance ( $\$ 50 \%$ stimulation or inhibition) are highlighted.

"Batch: Represents compounds tested concurrently in the same assay(s).

$\mathrm{gp}=$ Guinea pig: ham=Hamster; hum=Human

$\mathrm{R}=$ See Remarks (if any) at end of this section.

Merck Sharp \& Dohme Corp

Thursday, February 16, 2017 


\section{Experimental Results}

\begin{tabular}{|c|c|c|c|c|c|c|c|c|c|c|}
\hline Cat \# & Assay Name & Batch* & Spec, & Rep. & Conc. & $\%$ Inh. & $\mid \mathrm{C}_{50}{ }^{*}$ & $K_{i}$ & $\mathrm{n}_{\mathrm{H}}$ & $\mathbf{R}$ \\
\hline 252710 & Muscarinic $\mathrm{M}_{2}$ & 400077 & hum & 1 & $10 \mu \mathrm{M}$ & -13 & & & & \\
\hline 252810 & Muscarinic Ms & 400079 & hum & 1 & $10 \mu \mathrm{M}$ & -7 & & & & \\
\hline 252910 & Muscarinic Mt & 400078 & hum & 1 & $10 \mu \mathrm{M}$ & 2 & & & & \\
\hline 253010 & Muscarinic Ms & 400078 & hum & 1 & $10 \mu \mathrm{M}$ & 7 & & & & \\
\hline 257010 & Neuropeptide $Y Y$, & 400157 & hum & 1 & $10 \mu \mathrm{M}$ & 0 & & & & \\
\hline 257110 & Neuropeptide $Y Y_{2}$ & 400108 & hum & 1 & $10 \mu \mathrm{M}$ & -11 & & & & \\
\hline 258010 & Neuratensin NT, & 400199 & hum & 1 & $10 \mu \mathrm{M}$ & -16 & & & & \\
\hline 258590 & Nicotinic Acetylcholine & 400200 & hum & 1 & $10 \mu \mathrm{M}$ & -9 & & & & \\
\hline \multirow[t]{5}{*}{260210} & Opiate $\mathrm{k}(\mathrm{OP} 2, \mathrm{KOP})$ & 400068 & hum & 1 & $10 \mu M$ & 52 & & & & \\
\hline & & 400393 & hum & 1 & $10 \mu \mathrm{M}$ & 56 & $7,60 \mu \mathrm{M}$ & $3,04 \mu \mathrm{M}$ & 0.87 & \\
\hline & & & hum & 1 & $1 \mu M$ & 15 & & & & \\
\hline & & & hum & 1 & $0.1 \mu \mathrm{M}$ & 2 & & & & \\
\hline & & & hum & 1 & $10 \mathrm{nM}$ & -1 & & & & \\
\hline 260410 & Opiate $\mu(\mathrm{OP} 3, \mathrm{MOP})$ & 400068 & hum & 1 & $10 \mu \mathrm{M}$ & 24 & & & & \\
\hline 260600 & Orphanin ORL, & 400029 & hum & 1 & $10 \mu \mathrm{M}$ & -8 & & & & \\
\hline 265010 & Platelet Activating Factor (PAF) & 400225 & hum & 1 & $10 \mu \mathrm{M}$ & -1 & & & & \\
\hline 265600 & Potassium Channel [Katp] & 400095 & ham & 1 & $10 \mu \mathrm{M}$ & -5 & & & & \\
\hline 267500 & PPARY & 400172 & hum & 1 & $10 \mu \mathrm{M}$ & 30 & & & & \\
\hline 299005 & Progesterone PR-B & 400173 & hum & 1 & $10 \mu \mathrm{M}$ & 14 & & & & \\
\hline 268110 & Prostanoid EP, & 400049 & hum & 1 & $10 \mu \mathrm{M}$ & 45 & & & & \\
\hline 299006 & Prostanoid EP, & 400031 & hum & 1 & $10 \mu \mathrm{M}$ & 47 & & & & \\
\hline 268510 & Prostanoid FP & 400049 & hum & 1 & $10 \mu \mathrm{M}$ & 42 & & & & \\
\hline 268810 & Purinergic $\mathrm{P} 2 \mathrm{Y}$ & 400036 & rat & 1 & $10 \mu \mathrm{M}$ & -11 & & & & \\
\hline 269500 & Retinoid X Receptor RXRa & 400201 & hum & 1 & $10 \mu \mathrm{M}$ & -2 & & & & \\
\hline 271110 & Serotonin (5-Hydroxytryptamine) $5-H T_{1 A}$ & 400110 & hum & 1 & $10 \mu \mathrm{M}$ & 8 & & & & \\
\hline 271200 & Serotonin (5-Hydroxytryptamine) $5-H T_{18}$ & 400202 & rat & 1 & $10 \mu \mathrm{M}$ & 23 & & & & \\
\hline 271650 & Serotonin (5-Hydroxytryptamine) $5-H T_{2 A}$ & 400203 & hum & 1 & $10 \mu \mathrm{M}$ & 24 & & & & \\
\hline 271710 & $\begin{array}{l}\text { Serotonin (5-Hydroxytryptamine) } 5-\mathrm{HT}_{2 \mathrm{H}} \\
{[\mathrm{H} \mathrm{H}] \text { Mesulergine }}\end{array}$ & 400236 & hum & 1 & $10 \mu \mathrm{M}$ & 41 & & & & \\
\hline 271800 & Serotonin (5-Hydroxytryptamine) $5+1 T_{x}$ & 400049 & hum & 1 & $10 \mu \mathrm{M}$ & 6 & & & & \\
\hline 271910 & Serotonin (5-Hydroxylryplamine) $5-H T$, & 400111 & hum & 1 & $10 \mu \mathrm{M}$ & -17 & & & & \\
\hline 272200 & Serotonin (5-Hydroxytryptamine) $5-H_{4}$ & 400115 & hum & 1 & $10 \mu \mathrm{M}$ & -3 & & & & \\
\hline 282700 & Somatostatin sst2 & 400204 & hum & 1 & $10 \mu \mathrm{M}$ & 12 & & & & \\
\hline 255520 & Tachykinin $\mathrm{NK}_{1}$ & 400094 & hum & 1 & $10 \mu \mathrm{M}$ & 4 & & & & \\
\hline 255600 & Tachykinin NKz & 400037 & hum & 1 & $10 \mu \mathrm{M}$ & 13 & & & & \\
\hline 286000 & Thyrotropin Releasing Hormone (TRH) & 400035 & rat & 1 & $10 \mu \mathrm{M}$ & 7 & & & & \\
\hline
\end{tabular}

Note: Items meeting criteria for significance ( $250 \%$ stimulation or inhibition) are highlighted.

- Batch: Represents compounds tested concurrently in the same assay(s).

$\mathrm{gp}=$ Guinea pig: ham=Hamster; hum=Human

$\mathrm{R}=$ See Remarks (if any) at end of this section

Merck Sharp \& Dohme Corp

Thursday, February 16, 2017 


\section{Experimental Results}

\begin{tabular}{|c|c|c|c|c|c|c|c|c|c|c|}
\hline Cat \# & Assay Name & Batch* & Spec. & Rep. & Conc, & $\%$ Inh. & $\mid \mathbf{C}_{50}{ }^{*}$ & $K_{i}$ & $\mathrm{n}_{\mathrm{H}}$ & $\mathbf{R}$ \\
\hline \multirow[t]{5}{*}{202000} & Transporter, Adenosine & 400071 & $g \mathrm{p}$ & 1 & $10 \mu M$ & 55 & & & & \\
\hline & & 400239 & $g p$ & 1 & $10 \mu \mathrm{M}$ & 53 & $9.70 \mu \mathrm{M}$ & $3.32 \mu \mathrm{M}$ & 4.44 & \\
\hline & & & $g p$ & 1 & $1 \mu \mathrm{M}$ & -1 & & & & \\
\hline & & & $g p$ & 1 & $0.1 \mu \mathrm{M}$ & -18 & & & & \\
\hline & & & $g p$ & 1 & $10 \mathrm{~nm}$ & -3 & & & & \\
\hline 219000 & Transporter, Choline & 400194 & rat & 1 & $10 \mu \mathrm{M}$ & 6 & & & & \\
\hline \multirow[t]{5}{*}{220320} & Transporter, Dopamine (DAT) & 400075 & hum & 1 & $10 \mu \mathrm{M}$ & 68 & & & & \\
\hline & & 400257 & hum & 1 & $10 \mu \mathrm{M}$ & 69 & $4.23 \mu \mathrm{M}$ & $3.36 \mu \mathrm{M}$ & 0.90 & \\
\hline & & & hum & 1 & $1 \mu \mathrm{M}$ & 20 & & & & \\
\hline & & & hum & 1 & $0.1 \mu \mathrm{M}$ & 6 & & & & \\
\hline & & & hum & 1 & $10 \mathrm{nM}$ & 2 & & & & \\
\hline 226400 & Transporter, GABA & 400195 & rat & 1 & $10 \mu \mathrm{M}$ & 3 & & & & \\
\hline \multirow[t]{5}{*}{204410} & Transporter, Norepinephrine (NET) & 400075 & hum & 1 & $10 \mu \mathrm{M}$ & 88 & & & & \\
\hline & & 400256 & hum & 1 & $10 \mu \mathrm{M}$ & 83 & $0.93 \mu \mathrm{M}$ & $0.93 \mu \mathrm{M}$ & 0.91 & \\
\hline & & & hum & 1 & $1 \mu \mathrm{M}$ & 56 & & & & \\
\hline & & & hum & 1 & $0.1 \mu \mathrm{M}$ & 9 & & & & \\
\hline & & & hum & 1 & $10 \mathrm{nM}$ & -10 & & & & \\
\hline 274030 & $\begin{array}{l}\text { Transporter, Serotonin (5- } \\
\text { Hydroxytryptamine) (SERT) }\end{array}$ & 400070 & hum & 1 & $10 \mu \mathrm{M}$ & 9 & & & & \\
\hline 287530 & Vasopressin $V_{1 \AA}$ & 400067 & hum & 1 & $10 \mu \mathrm{M}$ & -4 & & & & \\
\hline 287560 & Vasopressin $V_{18}$ & 400205 & hum & 1 & $10 \mu \mathrm{M}$ & -11 & & & & \\
\hline 287610 & Vasopressin $V_{2}$ & 400063 & hum & 1 & $10 \mu \mathrm{M}$ & 5 & & & & \\
\hline \multicolumn{11}{|c|}{$\begin{array}{l}\text { Eurofins Panlabs, Inc, has an exclusive, worldwide limited use license from Synaptic Pharmaceutical Corporation to perform these assays: } \\
\text { Adrenergic Alpha } 1 D \text {, Adrenergic Alpha } 28 \text {, and Dopamine D5 for safety and selectivity profling. Eurofins Panalbs' license excludes performing } \\
\text { those assays in connection with drug discovery or development activites where the principal therapeutic mechanism of action of the test } \\
\text { compound involves selective binding to a licensed receptor. Customers may contact Synaptic directly if they believe they need a broader license. }\end{array}$} \\
\hline \multicolumn{11}{|c|}{ Remarks } \\
\hline
\end{tabular}

1) Substantial negative inhibition can be caused by physical properties or insolubility of compound in final reaction conditions.

Note: Items meeting criteria for significance ( $250 \%$ stimulation or inhibition) are highlighted.

- Batch: Represents compounds tested concurrently in the same assay(s).

gp=Guinea pig, ham=Hamster; hum=Human

$\mathrm{R}=$ See Remarks (if any) at end of this section.

Merck Sharp \&. Dohme Corp

Thursday, February 16, 2017 


\section{Experimental Results}

\begin{tabular}{|c|c|c|c|c|c|c|c|c|c|c|}
\hline Cat \# & Assay Name & Batch ${ }^{*}$ & Spec. & Tissue & Rep. & Conc, & Criteria & Resp. & Ag. & Ant. \\
\hline 338200 & $\begin{array}{l}\text { Peroxisome Prol ferator Activated } \\
\text { Receptor PPARA (PPARalpha) }\end{array}$ & 400308 & hum & E. coli & 1 & $10 \mu \mathrm{M}$ & $2 \pm 50 \%$ & & $1 \%$ & ND \\
\hline 338200 & $\begin{array}{l}\text { Peroxisome Prol Ierator Activated } \\
\text { Receptor PPARA (PPARalpha) }\end{array}$ & 400309 & hum & E. coli & 1 & $10 \mu \mathrm{M}$ & $2 \pm 50 \%$ & & ND & $2 \%$ \\
\hline
\end{tabular}

Note: Items meeting criteria for significance are highlighted.

- Batch: Represents compounds tested concurrently in the same assay(s).

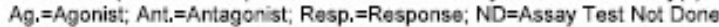

hum=Human

Merck Sharp \& Dohme Corp

Thursday, February 16, 2017 


\section{Panlabs results for Compound 13 (Figure S-2)}

\section{Figure S-2}

\section{Experimental Results}

\begin{tabular}{|c|c|c|c|c|c|c|c|c|c|c|}
\hline Cat \# & Assay Name & Batch* & Spec. & Rep. & Conc. & $\% \operatorname{lnh}$. & $\mathrm{IC}_{5}{ }^{*}$ & K & $\mathrm{n}_{\mathrm{H}}$ & $\mathbf{R}$ \\
\hline 217030 & Cannabinaid $\mathrm{CB}$, & 436292 & hum & 1 & $10 \mu \mathrm{M}$ & 4 & & & & \\
\hline 217100 & Cannabinoid $\mathrm{CB}_{2}$ & 436264 & hum & 1 & $10 \mu \mathrm{M}$ & 3 & & & & \\
\hline 217510 & Chemakine CCR1 & 436126 & hum & 1 & $10 \mu \mathrm{M}$ & -4 & & & & \\
\hline 244500 & Chemakine CXCR2 (IL-2RB) & 436267 & hum & 1 & $10 \mu \mathrm{M}$ & 3 & & & & \\
\hline 244550 & Chemakine CXCR4 & 436349 & hum & 1 & $10 \mu \mathrm{M}$ & -7 & & & & \\
\hline 218020 & Cholecystakinin $\mathrm{CCK}_{3}\left(\mathrm{CCK}_{a}\right)$ & 438184 & hum & 1 & $10 \mu \mathrm{M}$ & 30 & & & & \\
\hline 218130 & Cholecystakinin $\mathrm{CCK}_{2}\left(\mathrm{CCK}_{\mathrm{B}}\right)$ & 438184 & hum & 1 & $10 \mu \mathrm{M}$ & 19 & & & & \\
\hline 219150 & Corticotropin Releasing Factor CRF, & 436095 & hum & 1 & $10 \mu \mathrm{M}$ & -2 & & & & \\
\hline 299003 & CysLT $_{2}$ (LTC:s) & 436310 & hum & 1 & $10 \mu \mathrm{M}$ & 11 & & & & \\
\hline 219500 & Depamine Ds & 436273 & hum & 1 & $10 \mu \mathrm{M}$ & 11 & & & & \\
\hline 219700 & Dopamine Dss & 436218 & hum & 1 & $10 \mu \mathrm{M}$ & 6 & & & & \\
\hline 224010 & Endothelin ETA & 436166 & hum & 1 & $10 \mu \mathrm{M}$ & 4 & & & & \\
\hline 224110 & Endothelin ETs & 436260 & hum & 1 & $10 \mu \mathrm{M}$ & -3 & & & & \\
\hline 226010 & Estrogen ERa & 436100 & hum & 1 & $10 \mu \mathrm{M}$ & 6 & & & & \\
\hline 226810 & GABA, Chloride Channel, TBOB & 436109 & rat & 1 & $10 \mu \mathrm{M}$ & 12 & & & & \\
\hline 2266330 & GABA, Ro-15-1788, Hippocampus & 436266 & rat & 1 & $10 \mu \mathrm{M}$ & -15 & & & & \\
\hline 232030 & Glucocortionid & 436086 & hum & 1 & $10 \mu \mathrm{M}$ & 29 & & & & \\
\hline 237000 & Glutamate, Metabotropic, mGlus & 436149 & hum & 1 & $10 \mu \mathrm{M}$ & 7 & & & & \\
\hline 232810 & Glutamate, NNDA, Agonism & 436192 & rat & 1 & $10 \mu \mathrm{M}$ & 7 & & & & \\
\hline 232910 & Glutamate, NMDA, Gtycine & 436193 & rat & 1 & $10 \mu \mathrm{M}$ & -13 & & & & \\
\hline 233000 & Glutamate, NMDA, Phencyclidine & 438103 & rat & 1 & $10 \mu \mathrm{M}$ & 14 & & & & \\
\hline $23<000$ & Glutamate, NMDA, Polyamine & 436350 & rat & 1 & $10 \mu \mathrm{M}$ & -3 & & & & \\
\hline 239000 & Glycine, Strychnine-Sensitive & 436178 & rat & 1 & $10 \mu \mathrm{M}$ & 7 & & & & \\
\hline 239610 & Histamine $\mathrm{H}_{*}$ & 436118 & hum & 1 & $10 \mu \mathrm{M}$ & 11 & & & & \\
\hline 239710 & Histamine $\mathrm{H}_{2}$ & 436119 & hum & 1 & $10 \mu \mathrm{M}$ & -19 & & & & \\
\hline 239820 & Histamine $\mathrm{H}_{2}$ & 436294 & hum & 1 & $10 \mu \mathrm{M}$ & 10 & & & & \\
\hline 299035 & Histamine $\mathrm{H}_{4}$ & 436295 & hum & 1 & $10 \mu \mathrm{M}$ & -3 & & & & \\
\hline 299004 & $\mathrm{IP}(\mathrm{PGI})$ & 436108 & hum & 1 & $10 \mu \mathrm{M}$ & 19 & & & & \\
\hline 251010 & $\begin{array}{l}\text { Melanin-Concentrating Hormone MCH1 } \\
\text { (SLC1) }\end{array}$ & 436127 & hum & 1 & $10 \mu \mathrm{M}$ & 1 & & & & \\
\hline 251100 & Melanocortin MC 1 & 438110 & hum & 1 & $10 \mu \mathrm{M}$ & 5 & & & & \\
\hline 251300 & Melanocortin MCs & 436112 & hum & 1 & $10 \mu \mathrm{M}$ & 6 & & & & \\
\hline 251350 & Melanocortin MC4 & 436111 & hum & 1 & $10 \mu \mathrm{M}$ & -3 & & & & \\
\hline 251400 & Melanocortin MCs & 436112 & hum & 1 & $10 \mu \mathrm{M}$ & 17 & & & & \\
\hline 252610 & Muscarinic Mt & 436129 & hum & 1 & $10 \mu \mathrm{M}$ & 6 & & & & \\
\hline 252710 & Muscarinic $\mathrm{M}_{2}$ & 436128 & hum & 1 & $10 \mu \mathrm{M}$ & 19 & & & & \\
\hline
\end{tabular}

Note: Items meeting criteria for significance ( $250 \%$ stmulation or inhibition) are highlghted,

- Batch: Represerts compounds tested concurrently in the same assay(s).

$\mathrm{gp=Guinea} \mathrm{pig;} \mathrm{ham=Hamster,} \mathrm{hum=Human}$

Merck Sharp \& Dohme Corp

Tuesday, April 23, 2019 


\section{Experimental Results}

\begin{tabular}{|c|c|c|c|c|c|c|c|c|c|}
\hline Cat \# & Assay Name & Batch* & Spec. & Rep. & Conc. & $\%$ lnh. & $\mathrm{ICss}^{*}$ & K & nн $_{\text {н }}$ \\
\hline 252810 & Muscarinic $\mathrm{Ms}$ & 436130 & hum & 1 & $10 \mu \mathrm{M}$ & 6 & & & \\
\hline 252910 & Muscarinic Ms & 436131 & hum & 1 & $10 \mu \mathrm{M}$ & 8 & & & \\
\hline 253010 & Muscarinic Ms & 436294 & hum & 1 & $10 \mu \mathrm{M}$ & 0 & & & \\
\hline 257010 & Neurapeptide $Y Y_{1}$ & 436268 & hum & 1 & $10 \mu \mathrm{M}$ & -5 & & & \\
\hline 257110 & Neurapaptide $Y Y_{z}$ & 436204 & hum & 1 & $10 \mu \mathrm{M}$ & 4 & & & \\
\hline 258010 & Neuratensin NT, & 438339 & hum & 1 & $10 \mu \mathrm{M}$ & -16 & & & \\
\hline 258730 & Nicotinic Acetylcholine $\alpha 3 \beta 4$ & 436269 & hum & 1 & $10 \mu \mathrm{M}$ & -8 & & & \\
\hline 260210 & Opiate K (OP2, KOP) & 436211 & hum & 1 & $10 \mu \mathrm{M}$ & 17 & & & \\
\hline 260410 & Opiate $\mu(\mathrm{OP} 3, \mathrm{NOP})$ & 436212 & hum & 1 & $10 \mu \mathrm{M}$ & 12 & & & \\
\hline 260600 & Orphanin ORL 1 & 436197 & hum & 1 & $10 \mu \mathrm{M}$ & -17 & & & \\
\hline 265010 & Plate bat Activating Factor (PAF) & 436132 & hum & 1 & $10 \mu \mathrm{M}$ & -5 & & & \\
\hline 265600 & Potassium Channel [Kato] & 436143 & ham & 1 & $10 \mu \mathrm{M}$ & 4 & & & \\
\hline 267500 & PPARY & 436090 & hum & 1 & $10 \mu \mathrm{M}$ & 9 & & & \\
\hline 299005 & Progesterone PR-B & 436321 & hum & 1 & $10 \mu \mathrm{M}$ & 7 & & & \\
\hline 268110 & Prostanoid EP, & 436108 & hum & 1 & $10 \mu \mathrm{M}$ & 7 & & & \\
\hline 299006 & Prostanoid EP, & 436116 & hum & 1 & $10 \mu \mathrm{M}$ & 19 & & & \\
\hline 268510 & Prostancid FP & 436108 & hum & 1 & $10 \mu \mathrm{M}$ & 17 & & & \\
\hline 269500 & Retinoid X Receptor RXRa & 436089 & hum & 1 & $10 \mu \mathrm{M}$ & -8 & & & \\
\hline 271110 & Serotonin (S-Hydroxytryptamine) $5-T_{1 A}$ & 435190 & hum & 1 & $10 \mu \mathrm{M}$ & 21 & & & \\
\hline 271200 & Seratonin (S-Hydroxytryptamine) $5-T_{t \theta}$ & 436200 & rat & 1 & $10 \mu \mathrm{M}$ & -11 & & & \\
\hline 271650 & Serotonin (S-Hydroxylryptamine) $5-H T_{2 A}$ & 438147 & hum & 1 & $10 \mu \mathrm{M}$ & 37 & & & \\
\hline 271710 & 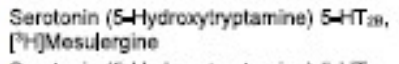 & 436285 & hum & 1 & $10 \mu \mathrm{M}$ & 41 & & & \\
\hline 271800 & Serotonin (5-Hydroxytryptamine) $5-\mathrm{H}_{2 c}$ & 436271 & hum & 1 & $10 \mu \mathrm{M}$ & 24 & & & \\
\hline 271910 & Serotonin ( 5 -Hydroxytryptaminc) $5-T_{s}$ & 436213 & hum & 1 & $10 \mu \mathrm{M}$ & 4 & & & \\
\hline 272200 & Serotonin (SHydroxytryptamine) S-THs & 436134 & hum & 1 & $10 \mu \mathrm{M}$ & 11 & & & \\
\hline 282700 & Somatostatin sst2 & 436202 & hum & 1 & $10 \mu \mathrm{M}$ & 5 & & & \\
\hline 255520 & Tachykinin NK, & 436172 & hum & 1 & $10 \mu \mathrm{M}$ & 10 & & & \\
\hline 255600 & Tachykinin $\mathrm{NK}_{2}$ & 436173 & hum & 1 & $10 \mu \mathrm{M}$ & 11 & & & \\
\hline 286010 & Thyrotrapin Releasing Homone (TRH) & 436203 & hum & 1 & $10 \mu \mathrm{M}$ & -3 & & & \\
\hline 202000 & Transporter, Adenosine & 438146 & gp & 1 & $10 \mu \mathrm{M}$ & 37 & & & \\
\hline 219000 & Transporter, Choline & 436396 & rat & 1 & $10 \mu \mathrm{M}$ & -5 & & & \\
\hline 220320 & Transporter, Dopamine (DAT) & 436265 & hum & 1 & $10 \mu \mathrm{M}$ & 23 & & & \\
\hline 226400 & Transporter, GABA & 436106 & rat & 1 & $10 \mu \mathrm{M}$ & -9 & & & \\
\hline 204410 & Transporter, Norepinaphrine (NET) & 436262 & hum & 1 & $10 \mu \mathrm{M}$ & 54 & $10.1 \mu \mathrm{M}$ & $9.97 \mu \mathrm{M}$ & B. 16 \\
\hline 204410 & Transporter, Norepinephrine (NET) & 436393 & hum & 1 & $10 \mu \mathrm{M}$ & 49 & $10.1 \mu \mathrm{M}$ & $9.97 \mu \mathrm{M}$ & 8.16 \\
\hline
\end{tabular}

Note: Items meeting criteria for significance ( $250 \%$ stmulation or inhibition) are highlighted.

- Batch: Represerts compounds tested concurrently in the same assay(s),

$g p=$ Guinea pig; ham=Hamster, hum=Human

Merck Sharp \& Dohme Corp

Tuesday, April 23, 2019 


\section{Experimental Results}

\begin{tabular}{|c|c|c|c|c|c|c|c|c|c|c|}
\hline Cat \# & Assay Name & Batch* & Spec. & Rep. & Conc. & $\%$ Inh. & $1 \mathrm{Cs}^{*}$ & $\kappa$ & $\mathrm{n}_{4}$ & $\mathbf{R}$ \\
\hline & & & hum & 1 & $1 \mu \mathrm{M}$ & -1 & & & & \\
\hline & & & hum & 1 & $0.1 \mu \mathrm{M}$ & 5 & & & & \\
\hline & & & hum & 1 & $10 \mathrm{nM}$ & -3 & & & & \\
\hline 274030 & $\begin{array}{l}\text { Transporter, Serotorin (5- } \\
\text { Hydroxytryptamine) (SERT) }\end{array}$ & 436214 & hum & 1 & $10 \mu \mathrm{M}$ & -3 & & & & \\
\hline 287530 & Vascpressin $V_{1 A}$ & 436272 & hum & 1 & $10 \mu \mathrm{M}$ & 0 & & & & \\
\hline 287560 & Vascoressin Vin & 436209 & hum & 1 & $10 \mu \mathrm{M}$ & 6 & & & & \\
\hline 287610 & Vascpressin $V_{2}$ & 436131 & hum & 1 & $10 \mu \mathrm{M}$ & -16 & & & & \\
\hline
\end{tabular}

Note: Items mecting criteria for significance (250\% stmulation or inhibition) are highlghted.

"Batch: Represerts compounds tested concurrently in the same assay(s).

gp=GLinea pig; ham=Hamster, hum=Human

Merck Sharp \& Dohme Corp

Tuesday, April 23, 2019 


\section{Experimental Results}

\begin{tabular}{|c|c|c|c|c|c|c|c|c|c|}
\hline Cat \# & Assay Name & Batch* & Spec. & Tissue & Rep. & Conc, Criteria & Resp. & $\mathrm{Ag}$. & Ant. $\mathrm{R}$ \\
\hline 338200 & $\begin{array}{l}\text { Percoisome Prolierator Activated } \\
\text { Receptor PPARA (PPARalpha) }\end{array}$ & 438448 & hum & E. coli & 1 & $10 \mu \mathrm{M} \approx \pm 50 \%$ & & $0 \%$ & ND \\
\hline 338200 & $\begin{array}{l}\text { Peroxisome Proliferator Activated } \\
\text { Receptor PPARA (PPARalpha) }\end{array}$ & 436449 & hum & E. coli & 1 & $10 \mu \mathrm{M}= \pm 50 \%$ & & ND & $-14 \%$ \\
\hline
\end{tabular}

Note: ltems meeting criteria for significanoe are highlghted.

- Batch: Represerts compounds tested concurrently in the same assay(s).

Ag.=Aganist; Ant,=Antaganist; Resp.=Response; ND=Assay Test Not Done

hum=ruman

Merck Sharp \& Dohme Corp

Tuesday, April 23, 2019 


\section{Abbreviations used in the Supporting Information for Publication}

\begin{tabular}{|c|c|}
\hline Abbreviation & Definition \\
\hline$\mu \mathrm{L}$ & microliter \\
\hline$\mu \mathrm{M}$ & micromolar \\
\hline$\mu \mathrm{mol}$ & micromolar \\
\hline $\mathrm{ACN}$ & acetonitrile \\
\hline ALIS & Automated Ligand Ide ntification System \\
\hline $\mathrm{API}$ & Active Pharmaceutical Ingredient \\
\hline conc. & concentration \\
\hline Ctrough & trough conce ntration \\
\hline $\mathrm{Cu}(\mathrm{l}) \mathrm{I}$ & copper (I) iodide \\
\hline $\mathrm{Da}$ & dalton \\
\hline DCM & dichloromethane \\
\hline DIEA, DIPEA & $\mathrm{N}, \mathrm{N}$-Dii sopropylethylamine \\
\hline DMF & Dime thylformamide \\
\hline DMSO & dimethyl sulfoxide \\
\hline $\mathrm{Et}_{3} \mathrm{~N}$ & triethylamine \\
\hline EtOAC & ethyl acetate \\
\hline $\mathrm{EtOH}$ & ethanol \\
\hline FassIF & fasted simulated small intestinal fluid \\
\hline $\mathrm{g}$ & gram \\
\hline $\mathrm{h}$ & hours \\
\hline $\mathrm{H}_{2}$ & hydrogen \\
\hline $\mathrm{H}_{2} \mathrm{O}$ & water \\
\hline HATU & $\begin{array}{l}\text { (1-[Bis (dimethylamino) methylene]-1H1,2,3-triazolo[4,5- } \\
\text { b]pyridinium 3-oxide hexafluorophosphate }\end{array}$ \\
\hline $\mathrm{HCl}$ & hydrogen chloride \\
\hline HPLC & High-perform ance liquid chromatography \\
\hline HT & High Th roughput \\
\hline IC50 & The half maximal inhibitory conce ntration \\
\hline IDO1 & Indoleam ine-2,3-dioxygenase-1 \\
\hline JackiePhos Pd G3 & $\begin{array}{l}{[(2-\{\text { Bis [3,5-bis(trifl uoromethyl)phenyl] phosphine }\}-3,6-} \\
\text { dimethoxy- 2', 4',6'-triiso propyl-1, 1'-biphe nyl )-2-(2'-amino-1,1'- } \\
\text { biphenyl)]palladium (II) methan esulfonate }\end{array}$ \\
\hline $\mathrm{K}_{2} \mathrm{CO}_{3}$ & potassium carbonate \\
\hline KHMDS & Potassium bis(trimethylsilyl)amide \\
\hline $\mathrm{KOH}$ & potassium hydroxide \\
\hline KOtBu & Potassium te rt-Butoxide \\
\hline LC & liquid chromatography \\
\hline $\mathrm{M}$ & molar \\
\hline $\mathrm{MeOH}$ & Methanol \\
\hline $\mathrm{mg}$ & milligram \\
\hline $\min$ & minutes \\
\hline $\mathrm{mL}$ & milliliter \\
\hline $\mathrm{mM}$ & millimolar \\
\hline MS & Mass Spectrometry \\
\hline
\end{tabular}




\begin{tabular}{|c|c|}
\hline Abbreviation & Definition \\
\hline $\mathrm{Na}_{2} \mathrm{SO}_{4}$ & Sodium sulfate \\
\hline $\mathrm{NaCl}$ & Sodium Chloride \\
\hline $\mathrm{NaH}$ & sodium hydride \\
\hline $\mathrm{NaHCO}_{3}$ & sodium bicarbonate \\
\hline $\mathrm{NaOH}$ & sodium hydroxide \\
\hline ng & nanogram \\
\hline $\mathrm{NH}_{4} \mathrm{Cl}$ & ammonium chloride \\
\hline NMR & Nuclear Magnetic Resonance \\
\hline${ }^{\circ} \mathrm{C}$ & degrees Celcius \\
\hline P450 & Cytochrome P450 \\
\hline $\mathrm{Pd} / \mathrm{C}$ & palladium on carbon \\
\hline PK & Pharmacokinetics \\
\hline PSI & pounds per square inch \\
\hline QC & quality control \\
\hline RPC & Reverse Phase Chromatography \\
\hline $\mathrm{rpm}$ & rate per minute \\
\hline SEC & Size Exclusion Chromatography \\
\hline SFC & supercritical fluid chromatography \\
\hline STD & standard \\
\hline$t-\mathrm{BuOH}$ & tert-butanol \\
\hline TEA & triethylamine \\
\hline TFA & Trifluoroacetic acid \\
\hline THF & Tetrahydrofuran \\
\hline UV-vis & Ultraviolet-visible spectroscopy \\
\hline $\mathrm{V}$ & Volt(s) \\
\hline
\end{tabular}

\section{References}

1. Procedure as reported in: Han, Y.; Achab, A.; Purakkattle, B.; Deng, Y.; Fradera, X.; Guo, L,; Hem S.; Kozlowski, J.; Kurukulasuriya, R.; Liu, K.; McGowan, M.; Pu, Q.; Sciammetta, N.; ZHang, H.; Zhou, H. "Novel compounds as indoleamine 2,3-dioxygenase inhibitors" US Patent Appl. 20180362482A1.

2. $\quad$ Procedure as reported in: Siu, T.; Altman, M. D.; Baltus, G. A.; Childers, M.; Ellis, J. M.; Gunaydin, H.; Hatch, H.; Ho, T.; Jewell, J.; Lacey, B. M.; Lesburg, C. A.; Pan, B. S.; Sauvagnat, B.; Schroeder, G. K.; Xu, S., Discovery of a Novel cGAMP Competitive Ligand of the Inactive Form of STING. Acs Med Chem Lett 2019, 10 (1), 92-97.

3. Obach, R. S., Prediction of human clearance of twenty-nine drugs from hepatic microsomal intrinsic clearance data: An examination of in vitro half-life approach and nonspecific binding to microsomes. Drug Metab Dispos 1999, 27 (11), 1350-9. 